\title{
Narrow versus broad vocational education: labour market position and curriculum characteristics of specialised versus less specialised vocational education programmes in the Netherlands
}

Citation for published version (APA):

Coenen, J. B., Heijke, J. A. M., \& Meng, C. M. (2014). Narrow versus broad vocational education: labour market position and curriculum characteristics of specialised versus less specialised vocational education programmes in the Netherlands. ROA. ROA Technical Reports No. 004

https://doi.org/10.26481/umarot.2014004

Document status and date:

Published: 01/01/2014

DOI:

10.26481/umarot.2014004

Document Version:

Publisher's PDF, also known as Version of record

Please check the document version of this publication:

- A submitted manuscript is the version of the article upon submission and before peer-review. There can be important differences between the submitted version and the official published version of record. People interested in the research are advised to contact the author for the final version of the publication, or visit the DOI to the publisher's website.

- The final author version and the galley proof are versions of the publication after peer review.

- The final published version features the final layout of the paper including the volume, issue and page numbers.

Link to publication

\footnotetext{
General rights rights.

- You may freely distribute the URL identifying the publication in the public portal. please follow below link for the End User Agreement:

www.umlib.nl/taverne-license

Take down policy

If you believe that this document breaches copyright please contact us at:

repository@maastrichtuniversity.nl

providing details and we will investigate your claim.
}

Copyright and moral rights for the publications made accessible in the public portal are retained by the authors and/or other copyright owners and it is a condition of accessing publications that users recognise and abide by the legal requirements associated with these

- Users may download and print one copy of any publication from the public portal for the purpose of private study or research.

- You may not further distribute the material or use it for any profit-making activity or commercial gain

If the publication is distributed under the terms of Article 25fa of the Dutch Copyright Act, indicated by the "Taverne" license above,

Download date: 26 Apr. 2023 


\section{Narrow versus broad vocational education:} Labour market position and curriculum characteristics of specialised versus less specialised vocational education programmes in the Netherlands

Johan Coenen Hans Heijke Christoph Meng

\section{ROA Technical Report}

ROA-TR-2014/4

Research Centre for Education and the Labour Market Maastricht University

P.O. Box 616,6200 MD Maastricht, The Netherlands

$\mathrm{T}+31433883647 \mathrm{~F}+31433884914$

secretary-roa-sbe@maastrichtuniversity.nl www.roa.nl 


\title{
Narrow versus broad vocational education: Labour market position and curriculum characteristics of specialised versus less specialised vocational education programmes in the Netherlands
}

\author{
Johan Coenen \\ Hans Heijke \\ Christoph Meng
}

ROA-TR-2014/4

August 2014 
Hans Heijke

Maastricht University

Department of Economics and ROA

P.O. Box 616

NL-6200 MD Maastricht

The Netherlands

h.heijke@maastrichtuniversity.nl
Christoph Meng

Maastricht University

ROA

P.O. Box 616

NL-6200 MD Maastricht

The Netherlands

c.meng@maastrichtuniversity.nl

Johan Coenen

Maastricht University

Top Institute for Evidence Based Education Research

P.O. Box 616

NL-6200 MD Maastricht

The Netherlands

johan.coenen@maastrichtuniversity.nl 


\begin{abstract}
This paper compares narrow, or specialised, and broad, or less specialised, upper-secondary vocational education (VE) programmes in the Netherlands with respect to their graduates' position in the labour market and how they assess a number of aspects of the programme they completed. The data used are from three years of the Dutch VE Monitor, a survey of secondary education graduates 18 months after graduation. The Level 4 programmes of the school-based learning route are investigated. To separate narrow from broad programmes, a new criterion is used, based on the idea that the match between education and a job within a narrow programme's own occupational domain is better than outside that domain and that for a broad programme such a match does not differ significantly between programme's own domain and outside that domain. The research shows that graduates from narrow, or specialised, education programmes have a less favourable labour market position than graduates from broad, or less specialised, programmes. They are more often forced to resort to jobs outside their programme's own domain and are less satisfied with their jobs. Further, it has been found that graduates from narrow programmes think that the programme should have concentrated less on subject-specific knowledge and its practical application. They feel a need for competencies that are more generally applicable. They further find that their programme was too easy more often than broadly educated graduates, which could indicate that narrow programmes have room to concentrate more on teaching competencies that would make graduates employable outside the programme's own domain.
\end{abstract}

JEL classification: I21, J24

Keywords: vocational programme, programme broadness, labour market position, curriculum characteristic

\title{
Acknowledgements
}

This paper is based on a study commissioned by the Dutch Centre for Expertise in Vocational Education and Training (ecbo): Johan Coenen, Hans Heijke, Christoph Meng, 'Smal versus breed beroepsonderwijs. Arbeidsmarktpositie en curriculumkenmerken van smalle versus brede opleidingen', ecbo, 's-Hertogenbosch/Utrecht, the Netherlands, December 2012. 


\section{Introduction}

A properly functioning economy requires the deployment of a wide variety of occupational skills. If the supply side of the labour market consisted exclusively of school-leavers with a general education, employers would face the costly task of teaching all lacking occupational skills themselves. The Netherlands, however, has an extensive vocational education (VE) system, covering both the secondary and tertiary education levels. As a result, almost half (45\%) of the population has completed a fullyfledged VE. ${ }^{1}$ This does not automatically mean, however, that this portion of the population is optimally prepared for their occupations after leaving school. After all, the diversity of the content and the levels of the education programmes completed must match the wide range of occupations, both qualitatively and quantitatively, that must be filled to allow the economy to function efficiently.

A good match implies that, having left school, relatively little needs to be invested in acquiring missing knowledge and skills in order to function properly in the occupation found. Ideally, the available VE programmes should turn out graduates who achieve a high level of productivity during the period in which they work in the occupations for which they have been trained. It is impossible, however, to match the supply of education programmes exactly to future employment in the occupations for which students are being trained and the changes that will take place in the content of these occupations, as well as the specific choices that future students will make, given the programmes offered. Not long after graduation, on average, a quarter of all graduates work outside the occupational domain of their own or a related education programme. ${ }^{2}$ An important question is therefore how to align VE with the volatile demands of the labour market and the educational choices to be made. The use of sound labour market forecasts and information on education programmes that also concentrates on the labour market perspectives of the education programmes offered will not be sufficient. In addition, VE should be set up so that the adaptation costs are minimal if changing labour market circumstances force workers to resort to occupations that are further removed from the specific occupations for which they were trained. Workers should also be ensured to adapt relatively easily to later changes in the content of their occupations that their VE could not anticipate. It has been argued for a long time that the adaptive power of secondary VE should be increased by broadening the education programmes offered in particular. ${ }^{3}$

Broadening VE programmes has both advantages and disadvantages. The broader, or less specialised, the programme, the easier the adaptation to both occupational requirements outside the programme's specific occupational domain and future innovations within the domain itself. A narrow programme, however, provides a high degree of specialisation in a particular discipline or a specific occupation. School-leavers who find a job in such an occupation shortly after graduation will perform better than others with a broader education. If there is insufficient work in this specific occupation, they will need to resort to a different one. There, they are likely to perform less well and will find it more difficult to adapt than those with broader training who find work in this occupation. In broadening an education programme, the lower costs of adaptation to different occupational requirements are offset by lower performance in a specialist occupation. Answering the question of broad versus narrow education

1. The figure was obtained from Statistics Netherlands (Statistics Netherlands 2011). It concerns the population with an education level from upper-secondary vocational education Level 4 to university education as a percentage of the population aged 15-65 years. University education is considered here as VE, albeit with a distinct academic component.

2. Research Centre for Education and the Labour Market (ROA) (2010).

3. In the Netherlands, this was prominently advocated by van Hoof and Dronkers (1980). For a more balanced assessment, see Borghans and de Grip (1999). 
programmes is therefore an economic consideration between these two implications of the programme for future labour market position. ${ }^{4}$

In this paper, we investigate the broadness aspect of VE programmes empirically. In doing so, we focus on upper-secondary VE. On the basis of a standard for the difference between broad and narrow education programmes, we ascertain the differences between these two types of programmes with regard to the labour market position of graduates, as well as differences in the curriculum characteristics as experienced by graduates.

For this, we make use of the VE Monitor, ${ }^{5}$ an annual survey on the labour market position of VE graduates about 18 months after graduation. In addition to their labour market position, respondents reflect on the education programme that they completed. The labour market data concern the position during the transition phase from school to work. The survey does not focus on any later changes in career or work content.

Dutch VE distinguishes two learning routes, both of which combine school education and practical training and result in formally equivalent diplomas. In the work-based learning route (the former apprenticeship system), the practical component dominates, whereas in the school-based learning route the school component does. This means that, in the work-based learning route, companies that take care of the practical component have a greater influence on the content of the programme than in the schoolbased learning route. This may mean, in practice, that the education programmes that work according to the work-based learning route have a narrower scope on the labour market. This is probably also the case for the work-based variants of education programmes offered through both learning routes. Education programmes offered through the work-based learning route not only are a priori narrower, but probably also exhibit less variation in their broadness than programmes that follow the school-based learning route. The larger practical component in the work-based learning route and closer ties with the companies that take care of this part of the programme may mean that this learning route offers a greater chance of finding a job after programme completion or of employment with the company in question. There are therefore differences in labour market opportunities between the two programme variants that are unrelated to the broadness of the programme but which appear to be statistically linked if no distinction is made between the learning routes. For these reasons, it is undesirable to consider both types of programmes together in a study on the relations between the broadness of the programme and labour market position. We therefore focus solely on programmes that follow the school-based learning route, where the link with the training companies plays a less important role.

In our study, we include only the education programmes at Level 4 (VE 4). Apart from the fact that the data set used contains too few respondents with an VE programme below this level, another argument for not including such programmes in the study is that they cannot be regarded as completed VE programmes. The programmes at Level 4 train for the occupational level of 'middle management official/specialised occupational'.

The setup of this paper is as follows. After this introductory section, section 2 compares narrow and broad education in greater detail. Section 3 discusses the data set used by the empirical study. An overview of some of the core data of the various education programmes is provided also. These core data are subsequently discussed. Section 4 develops a standard that can be used to distinguish between broad and narrow education programmes. This standard is then applied and the results discussed. This is followed by two sections containing analyses of the differences between broad and narrow education programmes. Section 5 analyses the differences with regard to labour market position and section 6

4. For a discussion of the issue of narrow versus broad education programmes, see, for example, Heijke and Borghans (1998), Borghans and de Grip (1999), Heijke (2001), and Dolton and Vignoles (2002).

5. In Dutch, the $M B O$ Monitor.

6. For the wider labour market opportunities of the work-based learning route, see, for example, ROA (2011). 
analyses the differences concerning some aspects of the curriculum. In section 7 our conclusions are drawn.

\section{Narrow or broad education programmes?}

\subsection{Introduction}

Purely from a labour market perspective, VE programmes should ideally be set up so that graduates achieve high productivity rates in their occupations during their working lives. In addition, the costs of adaptation should be minimal during the transition from school to work, when switching to a different occupation, and when occupational requirements change later in one's career. However, VE has a broader task than merely promoting an efficiently operating labour market. The law that regulates uppersecondary VE in the Netherlands states that this type of education should be aimed at providing theoretical and practical preparation for occupations for which a qualifying education is required or may be useful. ${ }^{7}$ In addition, VE is expected to promote the general education and personal development of students and to contribute to their social functioning. These two tasks of VE need not conflict and may even be an extension of each other. Expanding on this issue, however, is beyond the scope of this paper.

We now focus on the broadness of VE programmes. It is important to note that the first task specified by the law, by virtue of its focus on preparation for certain occupations, demarcates to some extent the broadness of VE programmes. The knowledge and skills to be taught in a VE programme focus primarily on the requirements for properly functioning in the specific occupations for which it intends to prepare its students. The second task concerns certain generic aspects, such as general education, which provide the broadness of a programme. Nevertheless, the setup of the occupational preparation portion of the programme may also contribute to its broadness. Concentrating a great deal on teaching basic knowledge in various disciplines will provide graduates with more flexibility in the labour market. The information technology (IT) knowledge acquired for occupations in the graphics industry, for example, may be applicable in other, more specific IT occupations. In the same way, basic biological knowledge for agricultural occupations may also be useful in horticultural occupations.

Decision making in the provision of publicly funded VE programmes is highly regulated. Schools can offer only education programmes whose final attainment levels are listed in the central VE programme register (CREBO). The final attainment levels can be described as the competencies in knowledge, insight, skills, and possibly occupational attitudes that graduates need to have to function properly in their occupations or that are important for further education. These final attainment levels were drawn up by industry-specific knowledge institutes that are closely allied to the organised business community. ${ }^{8}$ This is to ensure that the education programmes have labour market relevance. When the official regulation was evaluated, it was pointed out, by Borghans en Heijke (2004) in particular, that there was a risk that this link could be an obstacle to the creation of an adequate supply of education programmes that provide broad and lasting qualifications for occupational life. The strong link between the knowledge institutes and (the interests of) a particular industry could easily result in too much differentiation of education programmes, with insufficient attention to long-term aspects. The main fear in this respect concerns industry-transcending developments and new developments in the labour market,

7. Wet educatie en beroepsonderwijs (WEB), Article 1.2.1.

8. Strictly speaking, the institutes submit a proposal to the minister of education, who then formally determines the final attainment levels. 
teaching broadly applicable core competencies, as well as the personal development and social functioning of students. Schools have some play in determining part of their course material as they see fit. This enables them to adapt to the regional supply of students and/or the demands of the regional business community. It is important that schools focus on the preferences of students to ensure high course participation rates. This guarantees a high level of government funding for the schools. It is also important for schools to consider the preferences of the business community when deciding on the courses to offer. Businesses must be prepared to provide traineeships for students to acquire practical experience or to employ graduates, starting their occupational careers. If the supply of courses does not adequately match the demands and possibilities of the business community, this could harm the school's reputation.

For students, a narrow education programme can be highly motivating, because this enables them during their studies to form a clear image of what their desired occupation entails. A broad education programme, on the other hand, can be highly motivating for students who look at the long term or who are unsure what occupation they want to have. Students will want to consider the possibility that after graduation they will need to accept jobs outside the specific occupational domain of their education programme and that the content of the occupation may change over time. If schools focus primarily on students' short-term motives, the education programmes offered will become narrower.

If schools want to ensure that their courses match the business community's demands, similar considerations play a role. Businesses and institutes offering jobs to graduates from VE programmes may do so primarily to serve their short-term interests. Such organisations want students who wish to gain practical experience during their studies and graduates who want to be employed in regular jobs, to be capable of immediate involvement in the production process. In that case, organisations will be less inclined to consider the long-term interests of their young employees as a smooth adaptation to changes in later careers. They will also be less concerned about whether their young employees will be able to adapt properly to the introduction of new ways of doing their jobs. If schools also allow themselves to be guided by short-term motives with regard to the preferences of the business community, the education programmes offered will be narrowed.

Room for broadening VE programmes is limited if one wishes to maintain sufficient depth of the various topics to be taught. Apart from the room provided by the CREBO requirements, there are limits to the available length of the courses and the level of the students. The way of implementing this broadening is also important. Broadening in a subject-specific sense has completely different implications for the setup of the education programme than concentrating on the acquisition of generic skills. ${ }^{9}$ We elaborate on both options.

The subject-specific knowledge and skills taught in a VE programme focus on being able to function properly in a particular occupational domain. If the subject-specific knowledge concerns the basic knowledge of an occupation, its applicability extends to related occupational domains. For example, if the knowledge of wood that a carpenter needs to acquire in addition to processing also provides insight into a variety of other characteristics of wood, this knowledge can be applied in other occupations in the wood trade. If the curriculum concentrates on wood conservation options, the knowledge taught can be applied to the painting trade. If there is a greater concentration on automation in woodworking, along with basic aspects of IT, then the knowledge acquired can also be applied outside carpentry. In general, if subject-specific knowledge is required in multiple jobs, the education programme tends to be broader.

In addition to subject-specific knowledge and skills, VE programmes also teach general knowledge and skills. Apart from the specific knowledge required to function in society, this may also include the ability to function in work situations, effective cooperation with colleagues, adequate oral

9. For a more detailed discussion of this matter, see Nijhof (1998) and Borghans and de Grip (1999). 
communication skills, and the ability to quickly acquire new knowledge and skills. These types of knowledge and skills are required in almost all types of occupations. In general, therefore, the more the education programme concentrates on teaching these kinds of general skills, the broader the programme's perspective vis-à-vis the labour market. ${ }^{10}$

This means that many aspects and interests need to be considered when deciding on the required broadness of a VE programme. To this should be the limited understanding of the implications of completing a broad or narrow education programme for the subsequent labour market position of graduates. Hence, the broadness of the VE programmes offered will not always be socially optimal. With our research, we wish to contribute to improving this situation by providing insight into the practical effects of broad and narrow programmes on the labour market position of graduates. To this end, we focus on the experiences of VE graduates during the transition phase from education to a job. We also highlight the differences between broad and narrow education programmes in terms of how graduates judge a number of aspects of the programmes that they completed. The data set used is drawn from a survey among graduates held 18 months after their graduation, enabling us to define the situation during the transition from education to a job. However, this data set cannot be used to study long-term issues, such as the implications of the broadness of a programme for the graduates' occupational careers or their adaptability to later changes in how their occupations are practised.

\subsection{Broadness of programmes and labour market position}

As far as labour market position is concerned, our research looks at the differences between broad and narrow education programmes with regard whether graduates were still unemployed at the time of the survey, and if they had found a job, how long they searched for it, whether it was within the occupational domain of the education programme completed, and whether it was at the appropriate level. For graduates who had found a job, we also investigate the differences between those with a narrow education and those with a broad one with regard to their wages, whether they were satisfied with their jobs, how the jobs matched their education, and whether their knowledge and skills were sufficiently utilised.

What differences can be expected between narrow and broad education programmes on theoretical grounds for our empirical study into the above-mentioned aspects of labour market position? The answer to this question depends on the forces of supply and demand in the various occupational submarkets. If demand in a particular occupational domain is higher than the supply of graduates from education programmes preparing for this domain, the classical labour market mechanism tells us that the chances of unemployment are smaller, graduates need less time to find a job, and the chances of this job being at the level and within the domain of the education programme completed are greater. We can also expect wages in the jobs found to be better and satisfaction with the jobs found to be greater. Given these forces, we expect the broadness of the education programme to have the following effects.

Graduates from narrow, or specialised, education programmes are best prepared for the specific occupations targeted by the programme and are therefore preferred by employers providing jobs in these fields. If the supply of graduates sufficiently matches the demand for graduates in these specific occupational domains, graduates from narrow education programmes preparing for these domains will have a smaller chance of being unemployed than graduates from related, but broader, programmes. After all, graduates from these broader, less specialised, education programmes are less attractive for these specific occupations. In this situation, graduates from narrow education programmes will also be more

10. The statements about subject-specific and general skills are from our contribution to ROA (2007, Section 4). 
likely to find a job within the occupational domain and at the level of the programme completed. Because of their higher productivity within their own domain, wages will also be higher and, because of this, as well as the better match between their education and job they will be more satisfied with their jobs. If demand in these specific occupational domains decreases, however, those who completed narrow education programmes will face unemployment more quickly than the more broadly educated, because the specific nature of their education prevents them from being able to resort to other occupational domains. Once they have found a job outside the occupational domain of their education programme, the relatively unfavourable match will be likely to result in a job below the level of the education programme completed and their wages and satisfaction will be lower than among those with a broader education who work outside their occupational domain.

In addition to these changeable relations between supply and demand, structural factors also generally make it more difficult for narrow education programmes to match supply and demand. An example is the greater chance of an unequal geographic distribution of jobs in specialised occupational domains compared to the geographical distribution of graduates of matching narrow education programmes. Another structural factor is the decrease of occupational segmentation in industrial sectors resulting from IT developments, as in the printing industry. This means that the search for a job for graduates of the narrow education programmes in question will be longer.

We can summarise our expectations relating to the labour market position of graduates of narrow versus broad education programmes as follows. Since a mismatch between supply and demand in occupational submarkets is a rule rather than an exception and narrow education programmes provide a smaller chance of occupational change, we expect graduates from narrow programmes, in general, to face unemployment more often than graduates from broad programmes and that the former take longer to find a job. Furthermore, graduates from narrow programmes who have found a job in their own domain will be paid better, will be more satisfied, and will be more likely to have a job at their level than those from broader programmes who have found a job in their own domain. If graduates from narrow programmes need to resort to a job outside their occupational domain, however, we expect that such a job will pay less, will provide less satisfaction, and will be more likely to be below the level of their education programme than is the case among graduates from broader programmes working outside their own domain.

\subsection{Broadness of programmes and course characteristics}

If one wants to broaden an education programme with a view to improving graduates' labour market position, one needs to know which of its characteristics need to be changed. One option is to focus teaching more on knowledge that can be transferred to other occupational domains outside the programme's own specific domain. More attention could be paid to the basic principles of the various courses, such as general IT knowledge. Another option would be to teach more general skills that can be used across the entire labour market, such as socio-communicative skills that generally make the application of the available knowledge or working in teams much more effective.

In the VE Monitor, whose data set is used for this study, graduates are asked to look back on a number of aspects of the education programme that they have completed. In general, the question is what to change in the programme. Of all aspects with regard to this question, we only look at aspects relating to the content of the education programme or the competencies taught, as well as aspects that could affect the programme's usefulness in the labour market. One of the aspects considered, for example, is whether the education programme that has been completed should have paid more - or less - attention to subjectspecific knowledge. Unfortunately, this survey does not provide an absolute image of the current setup 
of the various education programmes. In the example given, the extent to which the programme already concentrated on subject-specific knowledge therefore remains unknown. The questions only concern the direction in which something should change in the education programme.

The aspects of the education programme reviewed include the following:

\section{Competencies}

- subject-specific knowledge;

- practical application of knowledge and skills;

- knowledge transfer;

- knowledge of IT;

- understanding operational management;

- foreign languages;

- understanding environmental and safety regulations;

- writing skills;

- oral skills;

- communication skills;

- working in a team/working together;

- planning, coordinating, organising activities;

- problem solving;

- commercial skills;

- independence;

- initiative, creativity;

- adaptability;

- accuracy, precision.

General characteristics of the curriculum

- basis for labour market entry;

- basis for developing knowledge and skills;

- broadness;

- depth;

- level of difficulty;

- ratio between theory and practice;

- options;

- challenging level.

In particular, the lack of information on the different aspects of the education programmes makes it difficult to define concrete expectations for the graduates' review of the programmes completed. This means that this part of the research primarily has empirical value. Nevertheless, we attempt to outline our expectations of the overall research findings.

With respect to the above-mentioned aspects relating to knowledge, a narrow education programme may be expected to concentrate a relatively large amount on the theory and practice of the specific occupational domain for which it prepares. Much less attention will be paid to imparting knowledge that is generally applicable or to general skills. Combined with the limited escape options that they have experienced in the labour market, graduates from narrow education programmes could therefore generally indicate that less attention should have been paid to subject-specific knowledge and its practical application. More attention should have been paid to widely applicable knowledge in fields 
such as IT, operational management, foreign languages, environment, and safety, as well as to general skills, for example, in the areas of communication and collaboration and planning and organisation or commercial skills. In line with this, these graduates might feel that their education programmes were too narrow, providing too much depth and too few alternative options. In addition, connection with the limited escape options in the labour market, graduates from narrow education programmes - particularly if they had to find jobs outside the occupational domain of their studies - might indicate that their education provides an inadequate basis for labour market entry and further development. With respect to the level of difficulty of the programme, the relations between theory and practice, and challenges offered, little can be said a priori. Any differences with respect to these aspects are therefore, first, an empirical issue, for which, at best, we could try to explain afterwards.

\section{Data and key data on education programmes}

\subsection{Data set}

As previously stated, to determine what constitutes a narrow, that is, specialised, or broad, that is, less specialised, vocational training programme, the VE Monitor, an annual survey among VE graduates, is used. This survey asks graduates about their labour market position approximately 18 months after graduation and about the match between the education programme completed and their jobs. Graduates are also asked to give their opinions on a variety of aspects of the completed programme. Our study aggregates the respondents from three years (2006-2008) to obtain a sufficiently large data set. This is important, particularly to differentiate optimally between the various education programmes. Our study focuses on Level 4 education programmes offered through the school-based learning route. To optimise the usefulness of further analyses, we require at least 15 workers for each education programme. This enables us to distinguish 41 education programmes, including six programmes in agriculture, 18 in technology, 10 in economics, four in health care, and three in behaviour and society.

\subsection{Key data of education programmes}

Table 1 specifies for each education programme the number of respondents and the percentage of graduates moving on to further education, a job, or other. Of those with jobs, the table also lists the percentage who found work within the occupational domain for which their own or a related education is required (hereafter referred to as 'own domain'). The data in the table are grouped into five education sectors: agriculture, technology, economics, health care, and behaviour and society.

The percentage of respondents listed in the category 'other' (i.e. who are neither attending an education programme nor in a job) is small. Thus, a high rate of graduates moving on to further education is reflected in a low rate of graduates moving into jobs and, vice versa, a low rate of graduates moving on to further education is reflected in a high rate of graduates moving into jobs. 
Table 1

VE 4 graduates moving on to further education, jobs (within or outside their own domain), and other (20062008 )

\begin{tabular}{|c|c|c|c|c|c|}
\hline \multirow[t]{2}{*}{ Education programmes } & \multirow[t]{2}{*}{$\begin{array}{r}\text { Respon- } \\
\text { dents } \\
(N)\end{array}$} & \multirow[t]{2}{*}{$\begin{array}{r}\text { Further } \\
\text { educa- } \\
\text { tion } \\
(\%)\end{array}$} & $J o b$ & \multirow{2}{*}{$\begin{array}{r}\text { Percent } \\
\text { in own } \\
\text { domain }^{a} \\
(\%) \\
\end{array}$} & \multirow[t]{2}{*}{$\begin{array}{r}\text { Other } \\
\\
(\%) \\
\end{array}$} \\
\hline & & & $(\%)$ & & \\
\hline \multicolumn{6}{|l|}{ Agriculture } \\
\hline Cultivation of Plants & 33 & 34.4 & 58.3 & 60.0 & 7.3 \\
\hline Cattle Breeding & 93 & 43.3 & 54.1 & 66.7 & 2.6 \\
\hline Animal Keeping \& Veterinary Support & 212 & 46.9 & 46.9 & 66.3 & 6.2 \\
\hline Horse Breeding \& Equestrianism & 43 & 46.3 & 44.4 & 36.8 & 9.3 \\
\hline Green Space & 118 & 43.4 & 52.8 & 63.0 & 3.8 \\
\hline Flower \& Garden Centre Sector & 52 & 34.6 & 58.9 & 65.4 & 6.5 \\
\hline Total & 608 & 45.4 & 49.6 & 63.8 & 5.0 \\
\hline \multicolumn{6}{|l|}{ Technology } \\
\hline Building & 264 & 65.3 & 31.8 & 84.7 & 2.9 \\
\hline Woodworking \& Interior Decoration & 43 & 32.6 & 58.4 & 56.0 & 9.0 \\
\hline Soil and Civil Engineering & 61 & 62.3 & 33.2 & 86.4 & 4.5 \\
\hline Protection \& Finishing Technology & 122 & 60.8 & 32.2 & 72.1 & 7.0 \\
\hline Advertising, Presentation \& Communication & 221 & 58.8 & 33.5 & 65.3 & 7.7 \\
\hline Operational Technology & 30 & 39.3 & 60.7 & 73.7 & 0.0 \\
\hline Mechanical Engineering & 225 & 58.5 & 39.5 & 83.0 & 2.0 \\
\hline Motor Vehicles & 89 & 53.4 & 36.2 & 76.3 & 10.4 \\
\hline Energy \& IT & 140 & 56.8 & 41.1 & 86.2 & 2.1 \\
\hline Energy Technology & 76 & 54.2 & 41.1 & 88.2 & 4.7 \\
\hline IT & 106 & 63.1 & 33.0 & 70.7 & 3.9 \\
\hline Graphics Techn., Communic., Audiovis. \& Multimedia & 228 & 61.6 & 31.8 & 71.6 & 6.6 \\
\hline Fashion \& Clothing Fabrication & 62 & 46.7 & 44.7 & 41.4 & 8.6 \\
\hline Photonics & 36 & 45.7 & 48.6 & 76.5 & 5.7 \\
\hline Laboratory Technology & 175 & 61.6 & 34.6 & 88.4 & 3.8 \\
\hline Harbour \& Transport & 74 & 37.5 & 59.8 & 73.8 & 2.7 \\
\hline Shipping & 56 & 21.4 & 78.6 & 94.4 & 0.0 \\
\hline Transport \& Logistics & 99 & 37.5 & 60.4 & 55.6 & 2.1 \\
\hline Total & 2282 & 56.1 & 39.1 & 75.7 & 4.8 \\
\hline \multicolumn{6}{|l|}{ Economics } \\
\hline Automation & 152 & 69.6 & 23.2 & 69.2 & 7.2 \\
\hline Business Administration & 387 & 67.6 & 28.6 & 6.2 & 3.8 \\
\hline Commercial & 466 & 69.7 & 25.8 & 54.1 & 4.5 \\
\hline Business Law & 135 & 78.4 & 12.9 & 46.4 & 8.7 \\
\hline Secretarial & 340 & 37.7 & 55.9 & 73.7 & 6.4 \\
\hline Retail/Street Trading & 441 & 50.1 & 42.2 & 44.3 & 7.7 \\
\hline Wholesale/Distribution & 115 & 81.8 & 12.3 & 60.0 & 5.9 \\
\hline General, Institution. Kitchen \& Contract Catering & 479 & 50.2 & 45.0 & 65.8 & 4.8 \\
\hline Tourism, Leisure \& Travel & 606 & 52.7 & 40.0 & 57.9 & 7.3 \\
\hline Automation Specialist & 274 & 68.8 & 26.2 & 78.0 & 5.1 \\
\hline Total & 3456 & 58.7 & 35.2 & 62.3 & 6.1 \\
\hline
\end{tabular}


Table 1 (continued)

\begin{tabular}{|c|c|c|c|c|c|}
\hline \multirow[t]{2}{*}{ Education programmes } & \multirow[t]{2}{*}{$\begin{array}{r}\text { Respon- } \\
\text { dents } \\
\\
(N)\end{array}$} & \multirow[t]{2}{*}{$\begin{array}{r}\text { Further } \\
\text { educa- } \\
\text { tion } \\
(\%)\end{array}$} & \multirow[t]{2}{*}{$\begin{array}{c}J o b \\
(\%)\end{array}$} & \multirow{2}{*}{$\begin{array}{r}\text { Percent } \\
\text { in own } \\
\text { domain }^{a} \\
(\%)\end{array}$} & \multirow[t]{2}{*}{$\begin{array}{r}\text { Other } \\
(\%)\end{array}$} \\
\hline & & & & & \\
\hline \multicolumn{6}{|l|}{ Health Care } \\
\hline Health Care Assistants & 516 & 27.8 & 67.5 & 90.4 & 4.7 \\
\hline General and Technical Support Services & 66 & 68.2 & 25.4 & 46.7 & 6.4 \\
\hline Sports \& Movement & 280 & 63.8 & 30.6 & 67.9 & 5.6 \\
\hline Nursing \& Care & 545 & 37.8 & 58.5 & 94.3 & 3.7 \\
\hline Total & 1421 & 40.7 & 54.8 & 88.8 & 4.5 \\
\hline \multicolumn{6}{|l|}{ Behaviour \& Society } \\
\hline Socio-Cultural Worker & 126 & 64,0 & 29,3 & 58,1 & 6,7 \\
\hline Socio-Pedagogical Work & 1991 & 61,6 & 33,4 & 84,9 & 5,0 \\
\hline Socio-Legal Work & 195 & 70,5 & 24,2 & 66,0 & 5,3 \\
\hline Total & 2324 & 62,5 & 32,4 & 82,2 & 5,1 \\
\hline Total VE 4 & 10091 & 55.7 & 38.9 & 74.3 & 5.4 \\
\hline
\end{tabular}

${ }^{\mathrm{a}}$ As a percentage of jobs.

Source: ROA, VE Monitor, 2006-2008.

A relatively high rate of moving on or a relatively low rate of workers finding a job in the education programme's own domain may be an indicator of a broad programme. To complete a (mostly) higher follow-up education programme, one needs to have completed a sufficiently broad range of basic subjects with a certain theoretical depth, resulting in the acquired knowledge becoming more than what is strictly necessary to function in the occupational domain of the VE programme in question. Furthermore, a relatively high rate of graduates who find jobs outside the education programme's own domain may point to a broad labour market perspective for the programme in question. However, the link between, on the one hand, the rate of moving on to further education and working outside the programme's domain and, on the other hand, the broadness of the programme is merely indicative, not only because the link need not be strong, but also because moving on to follow-up education and finding a job outside one's own domain are not merely related to the broadness of the programme. In particular, tension in the labour market can play a role. If there is too little work in the programme graduates' own domain, this can stimulate graduates to move on to further education. This way, can avoid the threat of unemployment and may improve their labour market position with a higher education level. In addition, the lack of work in their own domain may force graduates who prefer to work instead of continuing to further education to find a job outside the programme's own occupational domain.

Across VE 4 as a whole, the percentage of graduates moving on to further education is the highest (56\%), followed by the percentage moving into a job (39\%), three-quarters of whom found a job in the programme's own domain. Only a small percentage $(5 \%)$ is neither enrolled in an education programme nor in the labour market. The percentage of those moving on to further education varies greatly by programme. On average, this percentage is highest in the behaviour and society sector (63\%) and lowest in the health care sector $(41 \%)$. Variation within education sectors, however, can be great. Education programmes with a very high rate of graduates moving on to further education, $70 \%$ or more, can be found in the economics and behaviour and society sectors, notably automation (70\%), commercial 
(70\%), business law (78\%), and wholesale/distribution (82\%) within the former sector and socio-legal work $(71 \%)$ in the latter. Education programmes with a very low rate of graduates moving on to further education, $40 \%$ or less, can be found in all sectors except behaviour and society, which has the highest rate of such graduates: the cultivation of plants (34\%) and the flowers and garden centre sector (35\%) in agriculture; woodworking and interior decoration (33\%), operational technology (39\%), harbour and transport (38\%), shipping (21\%), and transport and logistics (38\%) within the technology sector; only secretarial (38\%) within the economics sector; and health care assistants $(28 \%)$ and nursing and care $(38 \%)$ within health care.

As stated above, in addition to a relatively high rate of graduates moving on to further education, a high rate of graduates moving into jobs outside their programmes' own domain may also be an indicator of a broad programme. Compared to the other sectors, graduates with jobs in the economics and agriculture sectors most often find jobs outside their education programme's own domain. The health care sector, however, has a very high percentage of graduates who find jobs within the programme's own domain (almost 90\%). Again, there are great differences between education programmes within a sector. Education programmes with a high rate of graduates, $40 \%$ or more, finding jobs outside the programme's own domain can be found in all sectors, ${ }^{11}$ for example, the cultivation of plants $(40 \%)$ and horse breeding and equestrianism (63\%) within the agriculture sector and woodworking and interior decoration (44\%), fashion and clothing (59\%), and transport and logistics (44\%) within the technology sector. Relatively many graduates end up working outside the programme's domain in the commercial (46\%), business law (54\%), retail/street trading (56\%), wholesale/distribution (40\%), and tourism, leisure, and travel (42\%) programmes within the economics sector. Only graduates of the general and technical support services programme work relatively often outside their own domain (53\%) within the health care sector, ${ }^{12}$ as well as only socio-cultural workers (42\%) within the behaviour and society sector. A very high percentage of working graduates who found jobs within the programme's own domain, approximately $90 \%$ or more - which may be an indicator of a specialised programme - can only be found in programmes within the technology and health care sectors: energy technology (88\%), laboratory technology (88\%), and shipping (94\%) within technology sector and health care assistants (90\%) and nursing and care (94\%) within the health care sector.

Moving on to further education and finding a job outside the education programme's own domain may reinforce each another when it comes to the broadness of the programme. We therefore analyse to what extent education programmes with a very high rate of graduates moving on to further education coincide with education programmes with a very high percentage of workers in jobs outside their own domain. On the other hand, we also check whether education programmes with a very low rate of graduates moving on to further education coincide with education programmes with a very high percentage of graduates working in their own domain. In doing so, we first look at the level of the education sectors and then the level of education programmes.

In the sector with, on average, the highest percentage of graduates moving on to further education, behaviour and society, only about $20 \%$ of those with jobs appear to be working outside the occupational domain of the education programme completed. On the other hand, the sector with the lowest rate of graduates moving on to further education, health care, appears to have the lowest rate of graduates having to resort to jobs outside their own domain. This would indicate a relatively high degree of specialisation in this sector.

11. The percentages of graduates working outside their own domain that are reported here are not listed in the table but can be found by subtracting the percentage of those working within their own domain from 100.

12. This programme was allocated in the health care sector not so much for content-specific reasons, but primarily for statistical ones. 
At the level of education programmes, we find that programmes that exhibit both a high rate of graduates moving on to further education and a high rate of workers in jobs outside their own domain so potentially broad or very broad programmes - can only be found in the economics sector, namely, commercial, business law, and wholesale/distribution. Education programmes with both a low rate of graduates moving on to further education and a low percentage of graduates working outside their own domain - so potentially (very) specialised - can be found in the technology sector, with shipping, and in the health care sector, with programmes for health care assistants and nursing and care.

The indicators used here for classification into narrow and broad programmes are probably too global. After all, there may be circumstances altering the relations between, on the one hand, the broadness of the education programme and, on the other hand, the rate of graduates moving on to further education and accepting jobs outside their programme's occupational domain. In this context, shifts in supply and demand in the labour market should be mentioned in particular. As discussed before, these may have a major effect on both the rate of graduates moving on to further education and the percentage having to find a job outside the education programme's own domain, regardless of the broadness of the programme.

We should also refer to the relations between moving on to further education and working inside or outside one's own domain. If many graduates move on to further education, relatively few enter the labour market. As a result, given a certain labour market situation, those who enter it have a greater chance of finding a job within their own domain. On the other hand if few move on to further education, relatively many graduates enter the labour market. Given the labour market situation, they will have to resort to jobs outside their own domain relatively more often. Furthermore, the percentage moving on to further education as an indicator of the broadness of an education programme may be distorted if this percentage is limited by the absence of a higher level programme that matches the VE programme in question. In the next section we therefore develop a more accurate measure for the demarcation of narrow versus broad education programmes.

\section{Demarcation of narrow and broad education programmes}

\subsection{Introduction}

Determining statistically what constitutes a narrow or a broad education programme can, in principle, be approached from two angles. In the case of one angle, a narrow education programme is distinguished from a broad one on the basis of characteristics of the curriculum, which is assumed to provide graduates with either a limited or a wide perspective of the labour market. The education programme characteristic that is often used in this case is the composition of subjects of the programme (e.g. Dolton and Vignoles 2002). In the case of the other angle, the broadness of the labour market perspective achieved for graduates is taken as the starting point for distinguishing between broad and narrow education programmes. In this case, one can look, for example, at the range of graduates in the labour market in terms of the number of occupations to which they have gained access (e.g. de Grip and Heijke 1989). In this paper, we adopt the second angle, in which the labour market perspective achieved is the starting point, but not on the basis of a quantitative measure, such as the number of occupations practised by graduates. We use a qualitative measure that indicates to what extent the education programme completed matches the requirements of jobs outside one's own occupational domain compared to an experienced match within one's own domain. The better the match with jobs outside 
one's own occupational domain compared to those within one's own domain, the broader the classification of the education programme.

On the basis of the available data set, the degree to which education and jobs match can be measured both objectively and subjectively. We first discuss the objective approach, using the wages earned by graduates in their jobs. Then we discuss the subjective approach, using the match between education and jobs as perceived by the graduates.

\subsection{Demarcation through wages}

The use of wages as a measure for the broadness of an education programme is based on the assumption that the education completed gives graduates a comparative productivity advantage in jobs in the occupational field of the education programme and thus in a job within the programme's own occupational domain. Graduates from this education programme will deliver the highest yield in these occupations and hence receive the highest wages. ${ }^{13}$ Comparative advantage here means that this advantage must be regarded as relative to that of graduates from other VE programmes. The education programme for butchers, for example, provides its graduates with subject-specific competencies that give them a comparative advantage when they have jobs in the butcher's trade. ${ }^{14}$ They will be able to operate better and hence more effectively than graduates from other VE programmes, such as that for shoemakers. The labour market benefits from graduated butchers working in the butcher's trade and shoemakers in the shoemaking trade. If these workers were to change places, for example, the allocation in the labour market would not be optimal, with adverse consequences for labour productivity and earned wages. The allocation in the labour market will not usually, therefore, occur according to this extreme example. The butcher and the shoemaker who work in each other's field will earn less than their more productive colleagues who work within their own occupational domain. If there is a great scarcity of butchers and a large surplus of shoemakers, however, shoemakers could be found working in the butcher's trade. In time, they will probably be able to make up for their relatively lower wages compared to colleagues who were trained in the butcher's trade, by gaining experience and acquiring the lacking subject-specific knowledge. Retraining for the butcher's trade will not be easy for a shoemaker and will require a certain effort. Switching to a different trade will be easier if the knowledge and skills from the education programme with a labour surplus can be used to some extent in the trade with a deficit. This could be the case if the education programme covered the core competencies of several occupational fields or if a great deal of attention was paid to the acquisition of generic skills that can be used in many trades or that provide graduates the ability to acquire any lacking knowledge and skills more easily.

If employers in certain occupations face a shortage of graduates from preferred VE programmes, they will start to recruit among graduates from programmes that are slightly removed from the preferred programmes. They will pass on the required adaptation costs to the newly hired employees. When hired, these newcomers will therefore earn less than their colleagues with more suitable educational backgrounds and also less than they would earn in occupations that do match their education and in which they would perform relatively better. This (theoretical) fact can be taken as a starting point for an objective measure of the programme's broadness. By assuming that the narrower the education programme, the greater the subject-specific specialisation, the greater the required adaptation in jobs

13. For the importance of subject-specific knowledge and skills in finding a job in one's own domain and the level of wages, see Heijke et al. (2003a, 2003b). For the job matching theory that lies behind this or the assignment model, see Jovanovic (1979) and Sattinger (1993), respectively.

14. For the following explanation, see Heijke (2008). 
outside one's own domain, and hence the greater the wage disadvantage compared to jobs within one's own domain - in other words, the greater the wage advantage in one's own domain. Therefore, also, the broader the education programme, the easier the adaptation outside one's own domain and hence the smaller the wage disadvantage compared to one's own domain - in other words, the smaller the wage advantage in one's own domain.

Using the data on working VE 4 graduates, we estimate for all education programmes the difference in wages between having a job in one's own occupational domain and having one outside that domain. In these estimates, gender, age, working at one's own level, working part-time, further education, and year were used as control variables. The estimation results are represented in Table A.1 in Appendix A. However, these results are insufficient: The estimated wage difference between working within and working outside one's own domain is not significant in nearly $90 \%$ of education programmes.

What presumably plays a part is the fact that many more factors influence the level of wages than the match between education and occupational domain and the control variables included. First, there are the supply and demand ratios for the various labour markets of occupations and education programmes. We can also refer to the programme-intrinsic aspects of the jobs, which can lead to compensating wage differences between occupational domains. Last, we note that adaptation mechanisms in the labour market are not fully functional. Given the data set used, however, these factors cannot be taken into account, at least not without great difficulties, when estimating the wage differences per education programme between the two types of domains. The estimated education-specific wage differences between the two domains therefore constitute an insufficiently reliable measure for the distinction between narrow and broad education programmes.

\subsection{Demarcation through graduates' matches between education and job}

\subsubsection{Background of the demarcation criterion}

The VE Monitor survey asks graduates to rank the match between their education and their present job. This question indicates the broadness or narrowness of an education programme. Graduates who completed a narrow, highly specialised education programme are well prepared for jobs within the programme's own domain. The knowledge and skills acquired, however, will be less useful in jobs outside the programme's own domain. The difference experienced in graduates' matches between both types of occupational domains will therefore be large for a narrow programme. The knowledge acquired in a broad programme is, by definition, transferable to jobs outside the programme's own domain. These graduates will therefore experience a better match outside the programme's own domain than graduates from narrow education programmes. The knowledge and skills acquired in the education programme, however, will constitute less favourable preparation for jobs in the programme's own domain than in the case of a narrow programme. The difference in graduates' matches between education and a job in the programme's own domain compared to matches experienced outside this domain will be small in the case of a broad programme, at least smaller than in the case of a narrow programme. The difference in the graduates' matches between the two domains can therefore be used as a measure for the distinction between narrow and broad education programmes.

The qualifications given by respondents to the match between the education that they completed and their jobs are subjective. One may wonder whether different types of respondents would not be better able to judge the match, such as officials from schools or employers. Education officials would be quite capable of indicating the intentions of the education programme in relation to performance in jobs that are part of the occupational field. We think, however, that they would be less able to indicate the extent 
of the match with the requirements of actual jobs, less well, at any rate, than graduates could do for the jobs that they have. By analogy, company officials will be able to indicate fairly well the requirements for certain jobs and their matching education programmes. Again, we doubt whether they would be better able than the young employees themselves to indicate to what extent the actually completed education programme is useful for the day-to-day performance requirements of their specific jobs. Our approach is therefore quite defensible and we take the perceived match between education and one's job as a measure for the demarcation of narrow and broad education programmes.

\subsubsection{Application of the demarcation criterion}

The VE Monitor questionnaire asks the following question relating to the match between graduates' education and their job: 'How is the match between the education that you completed and your present position?' Respondents can choose from the options bad, moderate, sufficient, and good. For the matching criterion, we combine the two positive answers sufficient and good. Using a binomial logistic regression analysis of the graduates' answers, we estimate for each education programme whether there is a significant difference between the graduates' match between their own occupational domain and outside it. The explanatory variables here are the graduate's education programme and whether this graduate works within the programme's own domain. A number of control variables are also taken into account. Appendix A discusses the regression analysis used in more detail.

On the basis of the results, we classify an education programme as narrow if the match between education and a job within the programme's own occupational domain is significantly better than outside this domain. Applying this criterion results in the classification of education programmes into narrow and broad ones, as indicated in Table 2, by means of X's (for the underlying estimates, see Table A.2).

There appear to be 23 narrow programmes and 18 broad ones. In the case of the broad programmes, the match in the programme's own domain never deviates significantly from the match outside the programme's own domain. For three broad programmes, however, the estimated coefficient indicating the difference in the match between the two types of occupational domains has an extreme absolute magnitude: operational technology, soil and civil engineering, and shipping. All three appear to be technical education programmes for which the number of respondents working outside the programme's own domain is very small, particularly because of the combination of the small number of working respondents and the large number working within their own domain. The latter would actually indicate a specialised education programme. One could therefore have doubts about the classification of these education programmes as broad. On the other hand, these programmes will have little effect on the analyses because of the small number of working respondents. ${ }^{15}$

According to the criterion used, only two of the six programmes in the agricultural education sector are broad. In the technology sector, however, more than half (11 out of 18) of the programmes are broad. Of the 10 economics programmes, only two are broad. In health care, most of the programmes are broad, three out of four. Within the behaviour and society sector, however, none of the programmes are classified as broad.

15. One solution would be to extend the data set by using data from more recent years. However, these data would coincide with the current period of recession, creating a split with the data from the previous years. 
Table 2

Classification of VE 4 education programmes as narrow or broad, based on the match between education and jobs

Narrow programme

Broad programme

Agriculture

Cultivation of Plants

X

Cattle Breeding

Animal Keeping \& Veterinary Support

$X$

Horse Breeding \& Equestrianism

Green Space

Flower \& Garden Centre Sector

$\mathrm{X}$

Technology

Building

Woodworking \& Interior Decoration

Soil and Civil Engineering

Protection \& Finishing Technology

Advertising, Presentation \& Communication

Operational Technology

Mechanical Engineering

Motor Vehicles

$\mathrm{X}$

$\mathrm{X}$

$\mathrm{X}$

Energy \& IT

Energy Technology

IT

Graphic Technology, Communic., Audiovisual \& Multimedia

Fashion \& Clothing Fabrication

Photonics

Laboratory Technology

$\mathrm{X}$

Harbour \& Transport

$\mathrm{X}$

Shipping

Transport \& Logistics

$\mathrm{X}$

$\mathrm{X}$

$\mathrm{X}$

$\mathrm{X}$

$\mathrm{X}$

$\mathrm{X}$

X

$x$

X

X

$\mathrm{X}$

$\mathrm{X}$

$\mathrm{X}$

$\mathrm{X}$

$\mathrm{X}$

$\mathrm{X}$

Economics

Automation

Business Administration

Commercial

X

$\mathrm{X}$

Business Law

$\mathrm{X}$

Secretarial

$\mathrm{X}$

Retail/Street Trading

Wholesale/Distribution

General, Institutional Kitchen, Contract Catering

Tourism, Leisure \& Travel

Automation Specialist

X

$\mathrm{X}$

$\mathrm{X}$

$\mathrm{X}$

$\mathrm{X}$

X

Health Care

Health Care Assistants

$\mathrm{X}$

General and Technical Support Services

$\mathrm{X}$

Sports \& Movement

$\mathrm{X}$

Nursing \& Care

X

Behaviour \& Society

Socio-Cultural Worker

Socio-Pedagogical Work

Socio-Legal Work

$\mathrm{X}$ 
The results for the technology sector are striking. In particular, in this sector, one would expect many narrow, specialist education programmes. It is possible that a great deal of technical knowledge can be transferred outside one's own occupational domain or the knowledge and skills acquired in technical education programmes have a strong general component. ${ }^{16}$ Investigation of this issue is, however, beyond the scope of this study. The VE Monitor does not provide any information on the transferability of subject-specific knowledge. To analyse this aspect, such information would have to be collected first. In Section 3, we try to construct indicators of the broadness of education programmes from the rate of graduates moving on to further education and the percentage of them working within the programme's own domain. We find that if we apply both variables simultaneously, the programmes of shipping, health care assistants, and nursing and care could be considered narrow, while the commercial, business law, and wholesale/distribution programmes could be considered broad. This result is hardly in line with those based on the differences in the degree of the matches between education and one's job between the programme's own domain and outside it. The classification only matches for the business law programme. However, we prefer the distinction between narrow and broad that is based on the match between education and job as experienced by the respondents. After all, this classification criterion is based on a direct evaluation of the content of the knowledge and skills acquired in the programme compared with the knowledge and skills required for the job. Then, a comparison is made for this criterion between the match with a specific segment of the labour market (the programme's own domain) and the match with a much wider occupational domain, which includes all occupations outside the programme's own domain that graduates from that programme practise. Compared to this, the classification criterion that is based on the number of graduates going to subsequent education and those working in their own occupational domain is much more indirect and less accurate, particularly because of the many other factors that have an effect on this criterion, in addition to the broadness of the programme. We therefore accept that the classification criterion based on the graduates' match between education and job may not be a perfect measure either, considering the comments made in the case of, for example, the technology sector as a whole and the individual programmes of operational technology, soil and civil engineering, and shipping.

\section{Labour market position of narrow versus broad education programmes}

\subsection{Labour market position indicators}

We investigate the differences in labour market positions between graduates from narrow, or specialised, education programmes and those from broad, or less specialised, education programmes by carrying out regressions analyses in which we relate various indicators of the labour market position with whether the programme completed is narrow or broad. Whether an education programme is narrow or broad is indicated here by means of a dummy variable that equals one if the programme is narrow and zero if the programme is broad. The estimated regression coefficient of this dummy variable then shows the effect of a narrow programme compared to that of a broad programme in the labour market position indicator in question.

16. What has become clear is the fact that a large portion of VE graduate technicians work outside the sectors industry and construction, particularly in commercial services (e.g. de Grip \& Marey 2006). 
The following labour market factors are taken into consideration: unemployment at the time of the survey, duration of the search for the first job, job at the level of the programme completed, job within the programme's occupational domain, gross hourly wages, ${ }^{17}$ match between education and job, utilisation of knowledge and skills, career perspectives, and job satisfaction. The way in which these factors are measured in the VE Monitor is not uniform. The unemployment item involves a question about whether the respondent was unemployed at the time of the survey, a binary variable, unemployed or not unemployed. This also applies to the questions of whether the job was at the level of the programme completed and whether the job was within the programme's own (or a related) domain. For the questions of whether the match between education and job is sufficient to good, whether knowledge and skills are utilised sufficiently, whether career prospects are good, and whether graduates are satisfied with their job, answers are graded on a scale ranging from not at all to to a high degree or from bad to good. In those cases, the grades indicated by respondents were turned into a binary variable by grouping all positive qualifications together and setting these off against the other, similarly grouped qualifications. With all these factors represented by binary variables, the effect of a narrow programme is estimated by means of a binomial logistic regression analysis. The two remaining factors are measured nominally. The duration of the search for the first job is in months and hourly wages are in euros. In these cases, an ordinary least squares (OLS) regression analysis is carried out.

In addition to the dummy variable that indicates whether an education programme is narrow or broad, a number of control variables are used in the estimated regression analyses, including gender, age and age squared, the year of the survey, successful completion of further education, discontinuation of further education, working in the programme's own domain, and working at the programme's level. The last two variables are included only in certain cases (to be specified). The other control variables recur in every analysis. ${ }^{18}$

\subsection{Effects of narrow versus broad education programmes on the labour market position}

The results of the regression analyses are shown in Table 3. The table shows for each labour market position indicator the size of the estimated effect of a narrow, or specialised, education programme and, if included as control variables in the analyses in question, the size of the effects of working in the occupational domain of the education programme completed and at the level of that programme (for full estimation results, see Table B.1 in Appendix B). In the discussion of the results, we include the expectations formulated in Section 2.

For narrow education programmes, it takes significantly longer before graduates find their first job. The chance of being unemployed approximately 18 months after graduation also appears to be significantly larger. This is in line with our expectation that, if the employment perspectives are less

17. We use hourly wages rather than weekly or monthly wages to correct for working part-time.

18. The estimates of the effects on labour market position of having completed a narrow programme may be biased by self-selection by students in a narrow or broad programme. In this case, unobserved characteristics of students may play a role and the choice of a narrow or broad programme may be partially based on the expected effects of such a choice on labour market position. This would create a bias in the estimate of the effects of the broadness of the programme on labour market position. However, we do not believe that this is a great problem. In our research, the control variables, in addition to the usual characteristics of age and gender, also include variables that reveal the educational choices made after the vocational programme that was completed. Here, the same unobserved characteristics would play a role as those that played a role in the choice of a narrow or broad VE programme, so that they would act as proxies. In addition, our research later shows that the broadness of the VE programme completed is not considered an issue, in spite of the poor labour market position generally experienced in the case of narrow programmes. So the labour market situation appears to play hardly any role in the considerations leading to the choice of a narrow or broad programme. 
favourable, narrow education programmes provide fewer escape options to occupations outside the programme's own domain.

It is striking that graduates from narrow education programmes have a significantly smaller chance of obtaining a job within the programme's own occupational domain and at its level. Both chances appear to be related. If our estimates take into account whether respondents work within their own domain, this appears to have a positive effect on the chance of having a job at the programme's level. Since the chances of working in one's own domain are lower for graduates from narrow education programmes, this has a negative effect on the chances of having a job at the level of the programme.

Table 3

Effects of a narrow programme, job in own domain and at right level on labour market position ${ }^{\mathrm{a}}$

\begin{tabular}{|c|c|c|c|}
\hline & $\begin{array}{c}\text { Narrow } \\
\text { programme }\end{array}$ & $\begin{array}{l}\text { Within own } \\
\text { domain }\end{array}$ & At the right level \\
\hline Unemployment (logit) & $0.524^{* *}$ & & \\
\hline Duration of search (OLS) & $0.144^{* *}$ & & \\
\hline Job within own domain (logit, level as control) & $-0.721^{* * *}$ & & $2.101 * * *$ \\
\hline Job at right level (logit) & $-0.385^{* * *}$ & & \\
\hline Job at right level (logit, domain as control) & -0.094 & $2.097 * * *$ & \\
\hline Log gross hourly wages (OLS) & $-0.097^{* * *}$ & & \\
\hline $\begin{array}{l}\text { Log gross hourly wages (OLS, domain and } \\
\text { level as controls) }\end{array}$ & $-0.081 * * *$ & $0.057 * * *$ & $0.126 * * *$ \\
\hline Sufficient/good education-job match (logit) & -0.131 & & \\
\hline $\begin{array}{l}\text { Sufficient/good education-job match (logit, } \\
\text { domain and level as controls) }\end{array}$ & 0.077 & $1.293^{* * * *}$ & $0.369 * * *$ \\
\hline $\begin{array}{l}\text { (Very) many career options (logit, domain and } \\
\text { level as controls) }\end{array}$ & -0.087 & 0.091 & $0.567 * * *$ \\
\hline $\begin{array}{l}\text { (Very) satisfied with job (logit, domain and } \\
\text { level as controls) }\end{array}$ & $-0.194 * *$ & $0.419 * * *$ & $0.500 * * *$ \\
\hline
\end{tabular}

${ }^{a}$ The superscripts ***,**, and * indicate significance at the $1 \%, 5 \%$, and $10 \%$ levels, respectively. Full estimation results are shown in Table B.1 of Appendix B.

Gross hourly wages turn out to be lower for graduates from narrow education programmes than for graduates from broad programmes. In this case, the chances of finding a job within the programme's own occupational domain and at its level appear to play a role. These chances in themselves have a significantly positive effect on wage levels. We find, however, that graduates from narrow education programmes have lower chances of both finding a job in the programme's own domain and at the programme's level. Both aspects therefore have a negative effect on the hourly wage level for graduates from narrow education programmes. 
We conclude from these results that graduates from narrow education programmes have an unfavourable labour market position. There is insufficient demand for graduates from these programmes, as a result of which it is more difficult for them to find a job in their specific occupational domain and at the programme's level. Because of the limited options of resorting to other occupational domains, it takes longer for them to find a job and they lose jobs more easily. This weaker labour market position results in lower wages than among graduates from broad programmes.

With respect to the match between education and job, we find it to be, generally speaking, not significantly better or worse among graduates with a narrow education than among those with a broad education. As expected, having a job at the level and within the domain of an education programme has a significantly favourable effect on the match. We recall, however, that the narrow education programmes are demarcated on the basis of the match's relatively large improvement for these programmes if one were to switch from a job outside the programme's own domain to a job within it. Because graduates from narrow programmes more often have jobs outside the programme's own domain and not at the programme's level, they generally fail in practice to achieve this more favourable matching option in the programme's own domain and at its level. This explains why graduates from narrow education programmes generally do not experience a significantly better match between their education and job compared with graduates from broad programmes.

Graduates from narrow education programmes do not experience significantly more career opportunities than graduates from broad programmes. It makes no difference, in this case, whether they work within their own occupational domain or outside it. What does make a difference is whether they have a job at the level of the programme completed. As expected, regardless of the broadness of the programme, graduates experience better career opportunities if they find a job at the level of the programme.

Lastly, it appears that graduates from narrow programmes are significantly less satisfied with their jobs than graduates from broad programmes. Having a job within the programme's own domain and at its level significantly increases their satisfaction. The lower job satisfaction of graduates with a narrow education is therefore undoubtedly related to the smaller chance they have of finding a job in the programme's own domain and at its level.

\section{Curriculum characteristics of narrow versus broad education programmes}

\subsection{Two groups of curriculum characteristics}

We investigate the differences between narrow, or specialised, and broad, or less specialised, education programmes for two groups of curriculum characteristics. The first group includes 18 competencies that are important for occupational practice and which may be covered in the education programme to a greater or lesser extent. The second group consists of a number of general curriculum characteristics. We discuss the differences in characteristics between narrow and broad education programmes group by group, starting with the competencies taught.

\subsection{Competencies}

The VE Monitor asks graduates to reflect on the programme that they completed and to indicate for each of 18 competencies whether the programme should have paid less attention, just as much attention, or 
more attention to it. To find the differences between narrow and broad education programmes, we focus on the two extreme positions, that is, whether the programme should have paid less or more attention to the competency in question. To this end, we use the question of whether the programme should have paid just as much attention to this competency as a reference for the answer options of less attention and more attention. The estimation of the differences in the answers to these questions between narrow and broad education programmes is carried out by means of a multinomial logistic regression analysis. This estimates the chance that more attention should have been paid to the competency concerned and the chances that less attention should have been paid to it, both in relation to the chance that just as much attention should have been paid to this competency. In this estimation, the dependent variables less attention, just as much attention, and more attention are binary and equal to one if less attention or more attention has to be paid and zero if not. The variable relating to the broadness of the programme is also binary and equals one if the programme completed by the respondent was narrow and zero if the programme was broad. In the estimation equations, we include a number of control variables, that is, the following variables in all cases: gender, age, age squared, year of the survey, successful completion of further education, and discontinuation of further education. ${ }^{19}$

The estimation results for each competency are presented in Table 4. The table only shows the estimations for the effect of a narrow versus a broad programme (for full estimation results, see Tables B.2a and B.2b). We first discuss the results for the (specific) occupational competencies and then those for the general competencies.

In Section 2, we express the expectation that a narrow education programme would pay relatively more attention to both the theory and practice of the specific occupational domain for which it trains its students. Since the labour market demands broader employability than the programme's own occupational domain, graduates from narrow programmes are expected to generally indicate that their education programme should have paid less attention to subject-specific knowledge. This proves to be the case. Graduates from narrow education programmes indicate significantly more often that subjectspecific knowledge and its practical application should have received less attention than graduates from broad programmes do. The amount of attention that is paid to the ability to transfer knowledge, however, need not change, according to the graduates.

In addition - and in line with our expectations regarding the competency of subject-specific knowledge - we expected narrow education programmes to have paid significantly more attention to teaching generally applicable knowledge and skills. This proves to be the case with regard to eight of the 15 general competencies, namely, understanding operational management, writing skills, oral skills, communication skills, problem solving, commercial skills, initiative and creativity, and (weakly significant) adaptation skills. On the other hand, significantly less attention should have been paid by narrow education programmes to understanding environmental and safety regulations. With regard to the attention that should have been paid to the remaining six competencies - knowledge of IT; foreign languages; working in a team/working together; planning, coordinating, organising activities; independence; and accuracy - no significant differences are found between narrow and broad programmes.

19. A selection problem can also arise here. For our opinion on this, see footnote 18 . 
Table 4

Effects of a narrow education programme on the required attention paid to competencies ${ }^{\mathrm{a}}$

\begin{tabular}{lcc}
\hline & $\begin{array}{c}\text { Less attention } \\
\text { needed }\end{array}$ & $\begin{array}{c}\text { More attention } \\
\text { needed }\end{array}$ \\
\hline Specific competencies & & $-0.364^{* * *}$ \\
Occupational knowledge & $0.458^{* *}$ & $-0.276^{* * *}$ \\
Applying knowledge and skills in practice & $0.428^{* *}$ & -0.076 \\
Knowledge transfer & 0.248 & -0.137 \\
General competencies & & $0.193^{* *}$ \\
Knowledge of IT & & 0.019 \\
Understanding operational management & 0.139 & 0.049 \\
Foreign languages & 0.148 & $0.413^{* * *}$ \\
Understanding environmental and safety regulations & -0.127 & $0.422^{* * *}$ \\
Writing skills & $0.391 * * *$ & $0.239^{* * *}$ \\
Oral skills & 0.126 & 0.000 \\
Communication skills & 0.130 & -0.009 \\
Working in a team/working together & 0.041 & $0.185^{* *}$ \\
Planning, coordinating, organising activities & 0.084 & $0.396^{* * *}$ \\
Problem solving & -0.039 & 0.097 \\
Commercial skills & 0.219 & $0.232^{* * *}$ \\
Independence & -0.133 & $0.172^{*}$ \\
Initiative, creativity & 0.121 & -0.116 \\
Adaptability & 0.151 & -0.122 \\
Accuracy & 0.366 & \\
\hline & & \\
\hline
\end{tabular}

\footnotetext{
${ }^{\text {a }}$ The superscripts $* * *, * *$, and $*$ indicate significance at the $1 \%, 5 \%$, and $10 \%$ levels. Full estimation results are shown in Tables B.2a (specific competencies) and B.2b (general competencies) of Appendix B.
}

\subsection{General characteristics}

We select eight questions from the VE Monitor related to the education programme curriculum's general characteristics. These are questions about the education programme as a basis for labour market entry, as well as for the further development of knowledge and skills; the programme's broadness, depth, and difficulty; the programme's theoretical or practical content; the alternative options offered; and, lastly, whether the programme was challenging. We now indicate for each question how the difference in the answers between narrow and broad education programmes is estimated.

Whether the education programme constitutes a good basis for labour market entry and the further development of knowledge and skills is answered by respondents on a five-point scale, ranging from not at all to to a high degree. In this scale, the middle qualification is neutral and the two highest qualifications are positive. In the analyses, the positive answers are combined into a single, positive qualification, as opposed to the three other qualifications, which range from neutral to negative. This transforms the answers into a binary variable that equals one for a positive answer and zero otherwise. The difference between a narrow and a broad education programme with regard to the degree to which the programme is considered a good basis for labour market entry as well as for the further development of knowledge and skills is estimated by means of a binomial logistic regression analysis. 
A seven-point scale was used to answer questions assessing the broadness of the education programme (ranging from much too narrow to much too broad), its depth (from far too little depth to far too much depth), its level of difficulty (from much too low to much too high), the relation between theory and practice (from far too theoretical to far too practical), and alternative options (from far too few to far too many). With respect to these questions, we combine the two most extreme qualifications (i.e. $1+2$ ) on one end and do the same for the two most extreme qualifications on the other end (i.e. $6+7)$. The resulting two clearly opposite qualifications are thus set off against the combination of the three remaining neutral and near-neutral qualifications $(3+4+5)$. The latter, more or less neutral qualifications therefore act as a reference category. This means, for example, that for the question about the relations between theory and practice, the qualifications that mark a strong theoretical orientation are taken together, as are the qualifications that mark a strong practical orientation, and these are set off against the neutral qualifications. This results in two binary variables that both take the value one in case of an extreme qualification and zero otherwise. The effect of a narrow education programme is estimated by means of a multinomial logistic regression analysis.

Table 5

Effects of a narrow education programme on general curriculum characteristics ${ }^{\mathrm{a}}$

Good basis for labour market entry (logit)

Good basis for the further development of knowledge and skills (logit)

Too narrow (multinomial logit)

Too broad (multinomial logit)

Too little depth (multinomial logit)

Too much depth (multinomial logit)

Too easy (multinomial logit)

Too difficult (multinomial logit)

Too theoretical (multinomial logit)

Too practical (multinomial logit)

Too few options (multinomial logit)

Too many options (multinomial logit)

Challenging with regard to the level (logit)

$-0.139 * *$

$-0.120^{*}$

0.055

0.013

$-0.181^{* *}$

0.165

$0.241 * * *$

0.062

$-0.079$

0.149

0.044

0.235

0.024

${ }^{\text {a }}$ The superscripts $* * *, * *$, and $*$ indicate significance at the $1 \%, 5 \%$, and $10 \%$ levels, respectively. Full estimation results are shown in Table B.3 in Appendix B.

The last question asks graduates to indicate whether the programme level was challenging. Again, a five-point scale is used, ranging from the qualification completely disagree to completely agree. For this question, the possible scores on the answer scale are converted into a binary variable that takes the value one if respondents agreed with the statement and zero otherwise, that is, if they were neutral or 
disagreed. Here, the effect of a narrow education programme is estimated using a binomial logistic regression analysis.

In all eight cases for which the regressions are carried out, the same control variables are used as for the competencies, namely, gender, age, age squared, the year of the survey, successfully completion of further education, and discontinuation of further education. ${ }^{20}$ The results of the estimations relating to these programme characteristics are presented in Table 5 (for the full estimation results, see Table B.3). These results are discussed group by group.

Given the fact that graduates of narrow education programmes relatively often need to accept jobs outside their programme's own domain, we expect that they consider the programme to be a good basis for labour market entry and for further development of their knowledge and skills relatively less often. This expectation appears to be confirmed by the estimation results, which are significantly negative for both statements, albeit the significance level of the programme constituting a good basis for further development is weak.

The expectation that graduates of narrow education programmes will consider their programmes too narrow, considering the small chances experienced of finding a job in the programme's own occupational domain and at its the level, turns out to be unfounded. Apparently, respondents do not link the limited broadness of the education programme to the limited options experienced of resorting to other occupational domains in the labour market. Nor do graduates from narrow education programmes state that they have too few options more often than graduates from broad programmes do. However, they do state significantly less than graduates from broad programmes that the programme completed had too little depth, but did not state the depth of the programme was too great. Apparently, they consider the depth of the programme completed as sufficient more so than graduates from broad programmes.

With regard to the programme's level of difficulty, its theoretical or practical content, and the degree to which its level is challenging, we express no expectations of the views of the graduates from narrow versus broad programmes. As far as the theoretical or practical content of the programme and the degree to which the programme was experienced as challenging, there is no significant deviation between the views of graduates from narrow programmes and those of graduates from broad ones. There is, however, a significant difference in the views on the level of difficulty of the programme. Graduates from narrow education programmes generally consider their programmes too easy. In light of our finding that narrow education programmes yield relatively unfavourable labour market positions, this prompts the conclusion that narrow programmes could be made more difficult. This could be accomplished, in particular, by broadening the curriculum and concentrating more on broad subject-specific knowledge and general competencies that would make graduates easily employable outside the programme's own domain.

\section{Summary and conclusions}

$\mathrm{VE}$ is subject to the eternal question of how broad the education programmes offered should be. In a narrow, specialist programme, the knowledge and skills taught aim to ensure that graduates experience a good match with the occupational requirements once they find a job in the specific occupational domain targeted by the programme. If they find a job outside this occupational domain, however, the match will not be as good. In a broad education programme, the knowledge and skills acquired can be transferred to occupations outside the programme's specific occupational domain. This offers graduates the possibility

20. Concerning a possible selection problem that might arise, see footnote 18 . 
of performing well in those occupations too. Broadly educated graduates therefore have a wider labour market perspective than narrowly educated ones. At the same time, graduates from narrow education programmes will often be preferred in jobs within the programme's specific occupational domain. However, their labour market position is vulnerable in the case of insufficient employment within the occupational domains in which they have this preferred position.

In this study, we have investigated how these theoretical expectations for narrow and broad education programmes turned out in practice during the transition phase from education to a job. For this purpose, we used data from three years of the VE Monitor surveys. These data concern the labour market position of graduates from VE 4 programmes in the school-based learning route 18 months after graduation. In addition to labour market position, we also determined for graduates from narrow and broad education programmes who had jobs, how differently they assessed a number of aspects of the programme that they had completed, from the point of view of the requirements of their jobs. For this, we also used the VE Monitor data set.

In our research, the narrow education programmes were separated from the broad programmes on the basis of the criterion that, for narrow programmes, the match between education and job within the programme's own occupational domain is better than that in other occupational domains and that, for broad education programmes, this match for both types of occupational domains does not differ significantly. We initially tried to create this demarcation on the basis of the wage difference between graduates who found jobs within their programme's own occupational domain and graduates with the same education who found jobs outside this domain. In doing so, the wage difference was regarded as an indicator of the differences in productivity and adaptation costs for these graduates between the two types of domains. This did not prove a productive approach, probably because of the interfering influence on this relation exerted by, among other things, the labour market situation in submarkets and compensating wage differences. Less noise was expected from a criterion based on the difference in the match between education and job as experienced by graduates working within their own domain compared to those who found jobs outside that domain. On the basis of this criterion, we found that the majority of the education programmes in the sectors of technology and health care were broad and that in the agriculture, economics, and behaviour and society sectors most - and in the latter sector even all of the programmes were narrow. Indications were found that this classification criterion may not be perfect either. Although we used the match criterion for this study, further investigation of the merits of this criterion would certainly be useful. This could include research on the transferability of subjectspecific knowledge and other competencies acquired in programmes to occupations outside the programme's own occupational domain.

Our research shows that graduates from narrow education programmes have a less favourable labour market position than graduates from broad programmes. Graduates from narrow education programmes have a more difficult time finding a job in their programme's own domain and at its level. Because of the more limited options of resorting to jobs outside their own occupational domain, it takes longer for them to find a job and they lose jobs more easily. Once they find a job, they earn less than graduates from broad education programmes.

Graduates from narrow education programmes, on average, do not experience a better match between their education and job than graduates from broad programmes. It is true that they experience a better match between their education and job within their own domain than outside it but, because of their less favourable labour market circumstances, they are forced more often than their colleagues from broad programmes to resort to jobs outside their programme's own domain.

On average, graduates from narrow education programmes also indicate that they have just as many career opportunities as graduates from broad programmes. On the other hand, they are less satisfied with their jobs. Since a job within the programme's own domain and at its level increases workers' degree of 
satisfaction, this lower average satisfaction level is undoubtedly the result of the much lower chances that graduates from narrow programmes have of finding such a job than their broadly educated colleagues.

The next step in the study consisted of determining the differences between graduates from narrow and broad programmes in their assessment of a number of their programmes' curriculum aspects. In this case, we looked at the subject-specific and general competencies in the curriculum and a number of general programme characteristics.

If we compare graduates from narrow programmes to those from broad ones, we find that the former think the programme should have paid less attention to subject-specific knowledge and its practical application. This is understandable if one realises that these graduates end up more often outside their programme's own occupational domain, where the subject-specific knowledge and skills acquired are less useful to them. They therefore feel a need for competencies that are more generally applicable. We found that graduates from narrow education programmes indeed felt the need for more attention during their studies to eight of the 15 distinct general competencies, namely, understanding operational management, writing skills, oral skills, communication skills, problem solving, commercial skills, initiative and creativity, and adaptation skills, and less attention to understanding environmental and safety regulations.

That graduates from narrow programmes end up in jobs outside their programme's own occupational domain more often than graduates from broad programmes has the obvious consequence that they regard their education programme less often as a good basis for labour market entry or for further development of their knowledge and skills.

In spite of the many negative aspects found here, graduates from narrow education programmes do not appear to find more often that the programme they completed was too narrow. Apparently, graduates do not make the link with the broadness of the programme, nor do they feel more often that they had too few options, and - more often than graduates from broad programmes - they find the depth of the programme sufficient. In addition, they do not think more often than their broadly educated colleagues that the programme was too theoretical or too practical, nor is there a difference between the degree to which they found the programme challenging. They do find more often than broadly educated graduates that their programme was too easy. This could indicate that narrow education programmes have room to concentrate more on teaching broad subject-specific knowledge and general competencies that would make graduates employable outside the programme's own domain.

Particularly where our findings on the unfavourable labour market position of graduates from narrow education programmes are concerned, we want to be cautious in drawing the conclusion that existing narrow programmes should therefore be broadened. Such a change should be carefully considered, keeping in mind the potential productivity losses or higher adaptation costs that would ensue in the programme's own occupational domain as a result of this broadening. We think it would be better to aim for a shift in the influx of students from narrow to broad education programmes. This would create a better balance between the supply of graduates from narrow programmes and the available employment within their own occupational domain. Fewer of them would then have to resort to jobs outside the programme's own occupational domain. At the same time, this would guarantee the sufficient potential of graduates to perform optimally within that domain, or at least better than graduates from related broader programmes could.

Shifting the student influx from narrow to broad programmes partly by offering broad variants of narrow programmes while maintaining the narrow, specialist variants may be highly allocation efficient. The narrow variants would then have to be offered on a smaller scale than before. This could prevent the productivity losses and adaptation costs that would ensue if employers can only recruit graduates from the broad variants for jobs within the occupational domain of narrow education programmes. 


\section{Appendix A. Estimation of the difference between narrow and broad VE programmes}

\section{Estimation based on wages}

To distinguish between narrow and broad education programmes on the basis of wages earned, the following wage equation is estimated by OLS:

$$
W_{i o b}=\alpha+\beta_{o} d_{i o}+\gamma_{o} d_{i o} d_{i b}+\delta X_{i}+\eta_{t} d_{i t}+\varepsilon_{i o b}
$$

The explanatory variable $W_{i o b}$ represents the natural logarithm of the hourly wage earned 18 months after graduation of a graduate $i$ who completed education programme $o$ and works in occupational domain $b$. We distinguish two educational domains: the education programme's own occupational domain and the external occupational domain. The variables $d_{i o}$ and $d_{i b}$ are dummy variables that equal one if the respondent completed education programme $o$ or works in the programme's own domain, respectively, and zero otherwise. The term $X_{i}$ is a vector denoting the graduate's individual characteristics, included in the equation as control variables: gender, working part-time, job at the programme's level, age, age squared, whether further education was pursued, and whether such education was completed or discontinued with a partial certificate. These are all dummy variables, except age which is measured in years. The interpretation of the dummy variables is obvious except the dummy for further education. About last variable should be noticed that it equals one if the further education was completed and if it was interrupted and equals zero if no further education was taken. The variable $d_{i t}$ is a dummy variable relating to the three survey years - 2006 to 2008 - that equals one for the first and second year and zero for last year. This variable represents changes over time that may affect the match between education and jobs, including shifts in the labour market. An error term, $\varepsilon_{i o b}$, with the usual properties is added to the equation.

The coefficient $\gamma_{o}$ indicates the (additional) effect on the hourly wage if one works in the programme's own occupational domain. It is used to distinguish between narrow and broad education programmes. We consider an education programme narrow if the estimated $\gamma_{o}$ is significantly positive, that is, the wage is higher within the programme's own domain than outside it. We classify an education programme as broad if the estimated $\gamma_{o}$ is not significantly different from zero or even negative. In that case, the wage between the programme's own domain does not differ from the wage outside it or may even be lower within that domain.

Only respondents younger than 36 years of age are considered in the estimation. This prevents the estimation results from being distorted by the inclusion of older graduates, whose labour market position could be considered as a less direct result of the VE programme completed 18 months before.

The estimation results for $\gamma_{o}$, combined under narrow and broad education programmes, and the estimation results for the other coefficients are presented in Table A.1. According to this classification criterion, only five of the 41 programmes would be narrow. Of these, three are technical programmes. Only two of these narrow programmes - laboratory technology and socio-pedagogical work - are also narrow on the basis of the criterion of the match between education and graduates' jobs discussed in the following section. 


\section{Agriculture}

$\begin{array}{ll}\text { Cultivation of Plants } & -0.128\end{array}$

$\begin{array}{lr}\text { Cattle Breeding } & 0.039\end{array}$

$\begin{array}{ll}\text { Animal Keeping \& Veterinary Support } & -0.079\end{array}$

Horse Breeding \& Equestrianism $\quad 0.132$

Green Space $\quad 0.032$

Flower \& Garden Centre Sector $\quad-0.031$

Technology

$\begin{array}{ll}\text { Building } & 0.042\end{array}$

Woodworking \& Interior Decoration $\quad 0.078$

$\begin{array}{ll}\text { Soil and Civil Engineering } & 0.000\end{array}$

$\begin{array}{lr}\text { Protection \& Finishing Technology } & 0.013\end{array}$

$\begin{array}{ll}\text { Advertising, Presentation \& Communication } & 0.082\end{array}$

$\begin{array}{ll}\text { Operational Technology } & 0.307 * *\end{array}$

Mechanical Engineering $\quad 0.040$

$\begin{array}{lr}\text { Motor Vehicles } & 0.125\end{array}$

$\begin{array}{ll}\text { Energy \& IT } & 0.137\end{array}$

Energy Technology $0.569 * * *$

IT

$-0.103$

Graphic Techn., Communication, Audiovisual, Multimedia 0.081

Fashion \& Clothing Fabrication $\quad-0.039$

Photonics

Laboratory Technology

$0.193 * *$

Harbour \& Transport

0.044

Shipping

$-0.336$

Transport \& Logistics

\section{Economics}

Automation

Business Administration

Commercial

$-0.037$

Business Law

$0.181 *$

Secretarial

0.062

Retail/Street Trading

$-0.018$

Wholesale/Distribution

$-0.035$

General, Institutional Kitchen, Contract Catering

$-0.017$

Tourism, Leisure \& Travel

Automation Specialist

$-0.059 *$

Health Care

Health Care Assistants

General and Technical Support Services

Sports \& Movement

Nursing \& Care

\section{Behaviour \& Society}

Socio-Cultural Worker

Socio-Pedagogical Work

$1.171 * * *$ 


$\begin{array}{lc}\text { Personal characteristics } & \\ \text { Female } & -0.082^{* * *} \\ \text { Age } & 0.196^{* * *} \\ \text { Age }^{2} & -0.003^{* * *} \\ & \\ \text { Job characteristics } & \\ \text { Part-Time } & 0.043^{* * *} \\ \text { At Right Level } & 0.090^{* * *} \\ & \\ \text { Further education } & \\ \text { No Further Education } & \text { ref. } \\ \text { Interrupted } & -0.033^{* *} \\ \text { Completed or Partial Certificate } & -0.059^{* *} \\ \text { Year } & \\ 2006 & -0.087^{* * *} \\ 2007 & -0.028^{* * *} \\ 2008 & \text { ref. } \\ \text { Constant } & \\ \text { Adjusted R } & -0.509 * * \\ \text { N } & \\ & \end{array}$

\footnotetext{
${ }^{\mathrm{a}}$ The superscripts $* * *, * *$, and * indicate levels, respectively. Sector dummies are not shown. significance at the
} $1 \%, 5 \%$, and $10 \%$

\section{Estimation based on the match between education and jobs}

To distinguish between narrow and broad education programmes on the basis of the match between the programme's own occupational domain and outside this domain, the following equation is estimated by binomial logistic regression analysis:

$Y_{i o b}=\zeta+\theta_{o} d_{i o}+\lambda_{o} d_{i o} d_{i b}+\kappa X_{i}+\mu_{t} d_{i t}+\pi_{i o b}$

Where the explanatory variable $Y_{i o b}$ indicates the assessment by graduate $i$ who completed education programme $o$ and works in domain $b$ of the match between the education programme completed and the current job. The variable is binary and takes the value one if the graduate indicates that the match between education and job is sufficient or good and zero in all other cases. All other variables have the same meaning as in the wage equation, Eq. (A.1). In addition, this estimation considers only respondents younger than 36 years.

The estimated coefficient $\lambda_{o}$ is the effect on the match if one works in the programme's own occupational domain. As for the wage criterion, we consider an education programme narrow if the estimated $\lambda_{o}$ is significantly positive. In that case, the match between education and one's job is better 
within the programme's own domain than outside it. An education programme is classified as broad if the estimated $\lambda_{o}$ is not significantly different from zero or even negative. In that case, the match between the programme's own domain does not differ from the match outside its own domain or may even be worse within that domain.

The estimation results for $\lambda_{o}$, combined under narrow and broad education programmes and for the other coefficients are presented in Table A.2. Of the 41 education programmes, 23, more than half of all the programmes, are narrow.

Table A.2. Classification of VE 4 education programmes into narrow and broad programmes, based on the match between education and one's job ${ }^{\mathrm{a}}$

Narrow programme Broad programme

Agriculture

Cultivation of Plants

$-1.083$

Cattle Breeding

$2.084 * *$

$2.687 * * *$

Animal Keeping \& Veterinary Support

$2.756 * *$

Horse Breeding \& Equestrianism

$2.095 * * *$

Green Space

Technology

Building

Woodworking \& Interior Decoration

Soil and Civil Engineering

Operational Technology

Mechanical Engineering

Motor Vehicles

$1.172 *$

Energy \& IT

$2.103 * *$

Energy Technology

IT

Graphic Technology, Communication, Audiovisual, Multimedia

Fashion \& Clothing Fabrication

Photonics

$2.472 * * *$

Laboratory Technology

$2.514 *$

Harbour \& Transport

$2.832 * *$

Shipping

Transport \& Logistics

\section{Economics}

Automation

Business Administration

$1.372 * * *$

Commercial

$1.271 * * *$

Business Law

$1.147 * * *$

Secretarial

$1.830 * * *$

Retail/Street Trading

$3.939 * * *$

Wholesale/Distribution

$1.506 * * *$

General, Institutional Kitchen, Contract Catering

$1.506 * * *$

Tourism, Leisure \& Travel

$1.534 * * *$ 
Table A.2 (continued)

\section{Health Care}

Health Care Assistants

General and Technical Support Services

Sports \& Movement

$2.864 * * *$

Nursing \& Care

\section{Behaviour \& Society}

Socio-Cultural Worker

Socio-Pedagogical Work

$1.036 * * *$

Socio-Legal Work

$1.459 * *$

\section{Personal characteristics}

Female

Age

$\mathrm{Age}^{2}$

\section{Job characteristics}

Part-Time

At Right Level

\section{Further education}

No Further Education

ref.

Interrupted

Completed or Partial Certificate

Year

2006

$-0.291 * * *$

2007

$-0.212 * *$

2008

ref.

Constant

$\mathrm{N}$

3540

${ }^{a}$ The superscripts $* * *, * *$, and $*$ indicate significance at the $1 \%, 5 \%$, and $10 \%$ levels, respectively. Sector dummies are not shown. 


\section{Appendix B. Effects of the broadness of VE programmes}

Table B.1. Effects of programme broadness on labour market position ${ }^{\mathrm{a}}$

\begin{tabular}{|c|c|c|c|c|c|c|c|c|c|c|c|}
\hline & $\begin{array}{l}\text { Unemploy- } \\
\text { ment }\end{array}$ & $\begin{array}{l}\text { Duration of } \\
\text { search }\end{array}$ & $\begin{array}{l}\text { Job within } \\
\text { own domain } \\
\text { (at right level) }\end{array}$ & $\begin{array}{l}\text { Job at right } \\
\text { level }\end{array}$ & $\begin{array}{l}\text { Job at right } \\
\text { level } \\
\text { (within own } \\
\text { domain) } \\
\quad \text { logit } \\
\end{array}$ & $\begin{array}{l}\text { Log gross } \\
\text { hourly wage }\end{array}$ & $\begin{array}{l}\text { Log gross } \\
\text { hourly wage } \\
\text { (job within } \\
\text { own domain, } \\
\text { at right level) } \\
\quad \text { OLS }\end{array}$ & $\begin{array}{l}\text { Sufficient/ } \\
\text { good } \\
\text { education-job } \\
\text { match } \\
\quad \text { logit }\end{array}$ & $\begin{array}{l}\text { Sufficient/good } \\
\text { education-job } \\
\text { match } \\
\text { (job within own } \\
\text { domain, at right } \\
\text { level) } \\
\quad \text { logit }\end{array}$ & $\begin{array}{l}\text { (Very) many } \\
\text { career options } \\
\text { (job within } \\
\text { own domain, } \\
\text { at right level) } \\
\quad \text { logit }\end{array}$ & $\begin{array}{l}\text { (Very) satisfied } \\
\text { with job } \\
\text { (job within own } \\
\text { domain, at right } \\
\text { level) } \\
\quad \text { logit }\end{array}$ \\
\hline Narrow programme & $0.524 * *$ & $0.144 * *$ & $-0.721 * * *$ & $-0.385^{* * *}$ & -0.094 & $-0.097 * * *$ & $-0.081 * * *$ & -0.131 & 0.077 & -0.087 & $-0.194 * *$ \\
\hline Job at right level & & & $2.101 * * *$ & & & & $0.126^{* * *}$ & & $0.369 * * *$ & $0.567 * * *$ & $0.500 * * *$ \\
\hline Job within own domain & & & & & $2.097 * * *$ & & $0.057 * * *$ & & $1.293 * * *$ & 0.091 & $0.419 * * *$ \\
\hline Part-time job & & & $0.353 * * *$ & $-0.181 *$ & $-0.319 * * *$ & $0.072 * * *$ & $0.073 * * *$ & 0.085 & 0.031 & $-0.601 * * *$ & $-0.530 * * *$ \\
\hline Female & 0.318 & $0.137 * *$ & -0.040 & $0.568^{* * * *}$ & $0.580 * * *$ & $-0.060 * * *$ & $-0.069 * * *$ & $0.159 *$ & 0.098 & $-0.255^{* * *}$ & $0.178^{* *}$ \\
\hline Age & 0.114 & $0.505 * * *$ & 0.137 & 0.226 & 0.139 & $0.196 * * *$ & $0.187 * * *$ & $-0.531 * * *$ & $-0.656 * * *$ & $0.286^{*}$ & $-0.445 * * *$ \\
\hline $\mathrm{Age}^{2}$ & 0.000 & $-0.009 * * *$ & -0.003 & -0.002 & 0.000 & $-0.003 * * *$ & $-0.003 * * *$ & $0.010 * * *$ & $0.012 * * *$ & $-0.006^{*}$ & $0.007 * *$ \\
\hline No further education & ref. & ref. & ref. & ref. & ref. & ref. & ref. & ref. & ref. & ref. & ref. \\
\hline Education interrupted & $1.166^{* * *}$ & 0.108 & $-0.346^{* * *}$ & -0.140 & 0.018 & $-0.047 * * *$ & $-0.040 * * *$ & $-0.216^{*}$ & -0.141 & 0.114 & $-0.216^{*}$ \\
\hline $\begin{array}{l}\text { Education completed or } \\
\text { partial certificate }\end{array}$ & $0.793^{*}$ & -0.207 & $0.906^{* * * *}$ & -0.183 & $-0.556^{*}$ & $-0.062 *$ & $-0.058^{*}$ & $0.573^{*}$ & 0.500 & 0.274 & 0.168 \\
\hline 2006 & $0.893 * * *$ & $0.566 * * *$ & 0.039 & $-0.193^{*}$ & -0.209 & $-0.071 * * *$ & $-0.070^{* * *}$ & $-0.227 * *$ & $-0.258^{* *}$ & -0.107 & 0.042 \\
\hline 2007 & 0.139 & $0.228 * * *$ & 0.082 & -0.101 & -0.145 & -0.016 & -0.014 & -0.118 & $-0.174 *$ & $-0.128 *$ & -0.047 \\
\hline 2008 & ref. & ref. & ref. & ref. & ref. & ref. & ref. & ref. & ref. & ref. & ref. \\
\hline Constant & -7.035 & $-6.388^{* * *}$ & -1.843 & -2.151 & -2.501 & -0.384 & -0.405 & $8.020 * * *$ & $8.480 * * *$ & -3.207 & $6.505^{* * *}$ \\
\hline Nagelkerke $\mathrm{R}^{2}$ & 0.057 & 0.020 & 0.211 & 0.031 & 0.230 & 0.152 & 0.197 & 0.013 & 0.125 & 0.055 & 0.059 \\
\hline -2 Log likelihood & 1088.196 & & 3618.516 & 3169.802 & 2691.892 & & & 4070.353 & 3703.426 & 4760.816 & 4246.953 \\
\hline $\mathrm{N}$ & 3881 & 3847 & 3668 & 3691 & 3668 & 3341 & 3292 & 3596 & 3540 & 3553 & 3555 \\
\hline
\end{tabular}


Table B.2a. Effects of programme broadness on concentration on specific competencies, multinomial logit ${ }^{\mathrm{a}}$

\begin{tabular}{|c|c|c|c|c|c|c|}
\hline & \multicolumn{2}{|c|}{$\begin{array}{l}\text { Attention to occupational } \\
\text { knowledge needed }\end{array}$} & \multicolumn{2}{|c|}{$\begin{array}{l}\text { Attention to applying knowledge } \\
\text { and skills in practice needed }\end{array}$} & \multicolumn{2}{|c|}{$\begin{array}{l}\text { Attention to knowledge transfer } \\
\text { needed }\end{array}$} \\
\hline & Less & More & Less & More & Less & More \\
\hline Narrow programme & $0.458 * *$ & $-0.364 * * *$ & $0.428 * *$ & $-0.276 * * *$ & 0.248 & -0.076 \\
\hline Female & -0.035 & -0.049 & -0.178 & $-0.184 * * *$ & $-0.513^{* * *}$ & -0.074 \\
\hline Age & 0.212 & -0.017 & -0.055 & 0.252 & -0.181 & -0.107 \\
\hline $\mathrm{Age}^{2}$ & -0.003 & 0.000 & 0.002 & -0.005 & 0.005 & 0.002 \\
\hline \multirow{3}{*}{$\begin{array}{l}\text { No further education } \\
\text { Education interrupted } \\
\text { Education completed or } \\
\text { partial certificate }\end{array}$} & ref. & ref. & ref. & ref. & ref. & \multirow{3}{*}{$\begin{array}{c}\text { ref. } \\
-0.047 \\
0.030\end{array}$} \\
\hline & $0.537 * *$ & $-0.316^{* *}$ & 0.054 & $-0.273 * *$ & 0.058 & \\
\hline & 0.567 & 0.239 & 0.307 & -0.152 & 0.465 & \\
\hline 2006 & 0.02 & -0.017 & 0.278 & 0.130 & 0.241 & -0.040 \\
\hline 2007 & $0.348 *$ & -0.012 & $0.441 * *$ & $0.163 * *$ & -0.020 & 0.109 \\
\hline 2008 & ref. & ref. & ref. & ref. & ref. & ref. \\
\hline Constant & -6.587 & -0.055 & -2.775 & -2.968 & -1.125 & 0.727 \\
\hline $\begin{array}{l}\text { Nagelkerke } \mathrm{R}^{2} \\
-2 \text { Log likelihood } \\
\mathrm{N}\end{array}$ & \multicolumn{2}{|c|}{$\begin{array}{c}0.019 \\
1068.034 \\
3492\end{array}$} & \multicolumn{2}{|c|}{$\begin{array}{c}0.018 \\
1056.789 \\
3478\end{array}$} & \multicolumn{2}{|c|}{$\begin{array}{c}0.08 \\
1025.925 \\
3468\end{array}$} \\
\hline
\end{tabular}

$\overline{{ }^{a}}$ The superscripts ***, **, and * indicate significance at the $1 \%, 5 \%$, and $10 \%$ levels, respectively. 
Table B.2b. Effects of programme broadness on concentration on general competencies, multinomial logit ${ }^{\mathrm{a}}$

\begin{tabular}{|c|c|c|c|c|c|c|c|c|c|c|c|c|}
\hline & \multicolumn{2}{|c|}{$\begin{array}{l}\text { Attention to } \\
\text { knowledge of IT } \\
\text { needed }\end{array}$} & \multicolumn{2}{|c|}{$\begin{array}{l}\text { Attention to } \\
\text { understanding } \\
\text { operational } \\
\text { management needed }\end{array}$} & \multicolumn{2}{|c|}{$\begin{array}{l}\text { Attention to foreign } \\
\text { languages needed }\end{array}$} & \multicolumn{2}{|c|}{$\begin{array}{l}\text { Attention to understanding } \\
\text { environmental and safety } \\
\text { regulations needed }\end{array}$} & \multicolumn{2}{|c|}{$\begin{array}{l}\text { Attention to writing skills } \\
\text { needed }\end{array}$} & \multicolumn{2}{|c|}{$\begin{array}{l}\text { Attention to oral skills } \\
\text { needed }\end{array}$} \\
\hline & Less & More & Less & More & Less & More & Less & More & Less & More & Less & More \\
\hline Narrow programme & 0.139 & -0.137 & -0.148 & $0.193^{* *}$ & 0.126 & 0.130 & $0.422 * * *$ & 0.049 & 0.126 & $0.413 * * *$ & 0.130 & $0.422^{* * *}$ \\
\hline Female & -0.017 & -0.137 & -0.054 & -0.129 & $-0.633 * * *$ & $-0.762 * * *$ & -0.026 & $-0.292 * * *$ & $-0.633^{* * *}$ & -0.111 & $-0.762 * * *$ & -0.026 \\
\hline Age & -0.159 & $0.335^{*}$ & 0,052 & 0.213 & -0.167 & 0.144 & $0.349^{*}$ & 0.300 & -0.167 & 0.354 & 0.144 & $0.349^{*}$ \\
\hline $\mathrm{Age}^{2}$ & 0.003 & -0.005 & 0,000 & -0.005 & 0.003 & -0.003 & $-0.007 *$ & -0.006 & 0.003 & -0.007 & -0.003 & $-0.007^{*}$ \\
\hline No further education & ref. & ref. & ref. & ref. & ref. & ref. & ref. & ref. & ref. & ref. & ref. & ref. \\
\hline Education interrupted & $0.324 *$ & -0.096 & $0.501 * * *$ & -0.081 & 0.034 & 0.160 & $0.229^{*}$ & 0.188 & 0.034 & $0.257 * *$ & 0.160 & $0.229 *$ \\
\hline $\begin{array}{l}\text { Education completed } \\
\text { or partial certificate }\end{array}$ & -0.023 & 0.412 & -0.155 & 0.188 & -0.296 & -0.383 & -0.193 & -0.205 & -0.296 & 0.134 & -0.383 & -0.193 \\
\hline 2006 & 0.117 & $0.218^{* *}$ & -0.021 & 0.080 & 0.123 & -0.167 & -0.060 & -0.067 & 0.123 & $-0.196 *$ & -0.167 & -0.060 \\
\hline 2007 & $0.253^{*}$ & 0,091 & 0.181 & 0.049 & -0.047 & 0.069 & 0.103 & 0.079 & -0.047 & -0.057 & 0.069 & 0.103 \\
\hline 2008 & ref. & ref. & ref. & ref. & ref. & ref. & ref. & ref. & ref. & ref. & ref. & ref. \\
\hline Constant & -0.607 & $-5.862 * *$ & -0.817 & -3.285 & 0,252 & -4.328 & $-5.548 * *$ & $-5.021 * *$ & 0,252 & $-6.064 * *$ & -4.328 & $-5.548^{*}$ \\
\hline Nagelkerke $\mathrm{R}^{2}$ & \multirow{2}{*}{\multicolumn{2}{|c|}{$\begin{array}{c}0.013 \\
1118307\end{array}$}} & \multicolumn{2}{|c|}{0.010} & \multicolumn{2}{|c|}{0.009} & \multicolumn{2}{|c|}{0.011} & \multicolumn{2}{|c|}{0.022} & \multicolumn{2}{|c|}{0.020} \\
\hline-2 Log likelihood & \multirow{2}{*}{\multicolumn{2}{|c|}{1118.307}} & \multirow{2}{*}{\multicolumn{2}{|c|}{$\begin{array}{c}1109.850 \\
3473\end{array}$}} & \multirow{2}{*}{\multicolumn{2}{|c|}{$\begin{array}{c}1218.692 \\
3481\end{array}$}} & \multirow{2}{*}{\multicolumn{2}{|c|}{1124.870}} & \multirow{2}{*}{\multicolumn{2}{|c|}{$\begin{array}{c}1082.742 \\
3475\end{array}$}} & \multirow{2}{*}{\multicolumn{2}{|c|}{$\begin{array}{c}1002.043 \\
3481\end{array}$}} \\
\hline $\mathrm{N}$ & & & & & & & & & & & & \\
\hline
\end{tabular}


Table B.2b (continued)

\begin{tabular}{|c|c|c|c|c|c|c|c|c|c|c|c|c|}
\hline & \multicolumn{2}{|c|}{$\begin{array}{l}\text { Attention to } \\
\text { communication skills } \\
\text { needed }\end{array}$} & \multicolumn{2}{|c|}{$\begin{array}{l}\text { Attention to working in a } \\
\text { team/working together } \\
\text { needed }\end{array}$} & \multicolumn{2}{|c|}{$\begin{array}{l}\text { Attention to planning, } \\
\text { coordinating, organising } \\
\text { activities needed }\end{array}$} & \multicolumn{2}{|c|}{$\begin{array}{l}\text { Attention to problem } \\
\text { solving needed }\end{array}$} & \multicolumn{2}{|c|}{$\begin{array}{l}\text { Attention to commercial } \\
\text { skills needed }\end{array}$} & \multicolumn{2}{|c|}{$\begin{array}{l}\text { Attention to independence } \\
\text { needed }\end{array}$} \\
\hline & Less & More & Less & More & Less & More & Less & More & Less & More & Less & More \\
\hline Narrow programme & 0.041 & $0.239 * * *$ & -0.039 & 0.219 & -0.133 & 0.121 & 0.151 & $0.185^{* *}$ & -0.133 & $0.396 * * *$ & 0.121 & 0.097 \\
\hline Female & $-0.910 * * *$ & 0.026 & $-0.541 * * *$ & $-0.560 * * *$ & $-0.402 * * *$ & $-1.042 * * *$ & -0.286 & $-0.205^{* * *}$ & $-0.402 * * *$ & $-0.342 * * *$ & $-1.042 * * *$ & $-0.213 * * *$ \\
\hline Age & 0.143 & 0.310 & -0.002 & $-0.834 * *$ & 0.081 & $-1.026 * *$ & -0.488 & -0.039 & 0.081 & 0.335 & $-1.026^{* *}$ & 0.129 \\
\hline $\mathrm{Age}^{2}$ & -0.002 & -0.006 & 0.000 & $0.017^{* *}$ & 0.000 & $0.019 * *$ & 0.010 & 0.000 & 0.000 & -0.007 & $0.019^{* *}$ & -0.003 \\
\hline No further education & ref. & ref. & ref. & ref. & ref. & ref. & ref. & ref. & ref. & ref. & ref. & ref. \\
\hline Education interrupted & 0.456 & $0.241 *$ & $0.407^{*}$ & $0.470^{*}$ & $0.363^{*}$ & 0.441 & 0.398 & -0.062 & $0.363^{*}$ & 0.081 & 0.441 & 0.151 \\
\hline $\begin{array}{l}\text { Education completed } \\
\text { or partial certificate }\end{array}$ & 0.446 & 0.228 & -1.233 & 0.558 & $-1.857^{*}$ & -0.498 & -0.617 & 0.344 & $-1.857^{*}$ & -0.149 & -0.498 & 0.264 \\
\hline 2006 & 0.031 & 0.067 & $0.476^{* * *}$ & 0.386 & -0.188 & -0.126 & -0.005 & 0.125 & -0.188 & 0.027 & -0.126 & 0.096 \\
\hline 2007 & -0.024 & 0.101 & 0.032 & $0.486^{* *}$ & -0.081 & 0.331 & 0.186 & $0.179 * *$ & -0.081 & 0.074 & 0.331 & 0.057 \\
\hline 2008 & ref. & ref. & ref. & ref. & ref. & ref. & ref. & ref. & ref. & ref. & ref. & ref \\
\hline Constant & -4.648 & $-4.998^{* *}$ & -2.406 & 6.967 & -3.482 & $10.315^{*}$ & 2.548 & -1.108 & -3.482 & -5.597 & $10.315^{*}$ & -2.357 \\
\hline Nagelkerke $\mathrm{R}^{2}$ & \multirow{2}{*}{\multicolumn{2}{|c|}{0.016}} & \multicolumn{2}{|c|}{0.017} & \multicolumn{2}{|c|}{0.011} & \multicolumn{2}{|c|}{0.014} & \multicolumn{2}{|c|}{0.023} & \multicolumn{2}{|c|}{0.017} \\
\hline-2 Log likelihood & \multirow{2}{*}{\multicolumn{2}{|c|}{$\begin{array}{c}1000.743 \\
3466\end{array}$}} & \multirow{2}{*}{\multicolumn{2}{|c|}{$\begin{array}{c}966.743 \\
3471\end{array}$}} & \multirow{2}{*}{\multicolumn{2}{|c|}{$\begin{array}{c}1092.138 \\
3472\end{array}$}} & \multirow{2}{*}{\multicolumn{2}{|c|}{$\begin{array}{c}1074.652 \\
3472\end{array}$}} & \multirow{2}{*}{\multicolumn{2}{|c|}{$\begin{array}{c}1128.203 \\
3467\end{array}$}} & \multirow{2}{*}{\multicolumn{2}{|c|}{$\begin{array}{l}934.802 \\
3470\end{array}$}} \\
\hline $\mathrm{N}$ & & & & & & & & & & & & \\
\hline
\end{tabular}

${ }^{a}$ The superscripts $* * *, * *$, and $*$ indicate significance at the $1 \%, 5 \%$, and $10 \%$ levels, respectively. 
Table B.2b (continued)

\begin{tabular}{|c|c|c|c|c|c|c|}
\hline & \multicolumn{2}{|c|}{$\begin{array}{l}\text { Attention to initiative and } \\
\text { creativity needed }\end{array}$} & \multicolumn{2}{|c|}{$\begin{array}{l}\text { Attention to adaptability } \\
\text { needed }\end{array}$} & \multicolumn{2}{|c|}{$\begin{array}{l}\text { Attention to accuracy } \\
\text { needed }\end{array}$} \\
\hline & Less & More & Less & More & Less & More \\
\hline Narrow programme & -0.122 & 0.366 & -0.116 & -0.122 & 0.366 & -0.116 \\
\hline Female & $-0.555^{* * *}$ & $-1.041 * * *$ & $-0.244 * * *$ & $-0.555 * * *$ & $-1.041 * * *$ & $-0.244 * * *$ \\
\hline Age & -0.143 & -0.414 & -0.072 & -0.143 & -0.414 & -0.072 \\
\hline $\mathrm{Age}^{2}$ & 0.004 & & 0.001 & 0.004 & & 0.001 \\
\hline No further education & ref. & ref. & ref. & ref. & ref. & ref. \\
\hline Education interrupted & 0.187 & 0.465 & 0.095 & 0.187 & 0.465 & 0.095 \\
\hline $\begin{array}{l}\text { Education completed } \\
\text { or partial certificate }\end{array}$ & $0.806^{*}$ & 0.681 & -0.032 & $0.806^{*}$ & 0.681 & -0.032 \\
\hline 2006 & 0.098 & -0.024 & -0.086 & 0.098 & -0.024 & -0.086 \\
\hline 2007 & 0.191 & 0.370 & 0.067 & 0.191 & 0.370 & 0.067 \\
\hline 2008 & ref. & ref. & ref. & ref. & ref. & ref. \\
\hline Constant & -1.431 & 1.564 & 0.720 & -1.431 & 1.564 & 0.720 \\
\hline Nagelkerke $\mathrm{R}^{2}$ & \multirow{2}{*}{\multicolumn{2}{|c|}{$\begin{array}{r}0.010 \\
048807\end{array}$}} & \multirow{2}{*}{\multicolumn{2}{|c|}{$\begin{array}{c}0.012 \\
058068\end{array}$}} & \multicolumn{2}{|c|}{0.018} \\
\hline-2 Log likelihood & & & & & \multirow{2}{*}{\multicolumn{2}{|c|}{$\begin{array}{l}00.492 \\
3466\end{array}$}} \\
\hline $\mathrm{N}$ & \multicolumn{2}{|c|}{$\begin{array}{c}948.807 \\
3467\end{array}$} & \multicolumn{2}{|c|}{$\begin{array}{l}34003 \\
3463\end{array}$} & & \\
\hline
\end{tabular}

${ }^{a}$ The superscripts $* * *, * *$, and $*$ indicate significance at the $1 \%, 5 \%$, and $10 \%$ levels, respectively. 
Table B.3. Effects of programme broadness on general curriculum characteristics ${ }^{\mathrm{a}}$

\begin{tabular}{|c|c|c|c|c|c|c|c|c|c|c|c|c|c|}
\hline & \begin{tabular}{l} 
Good basis \\
for labour \\
market entry \\
\multicolumn{1}{c}{ logit } \\
\end{tabular} & $\begin{array}{l}\text { Good basis for } \\
\text { further } \\
\text { development of } \\
\text { knowledge and } \\
\text { skills } \\
\quad \text { logit } \\
\end{array}$ & Too narrow & Too broad & $\begin{array}{l}\text { Too little } \\
\text { depth }\end{array}$ & $\begin{array}{l}\text { Too much } \\
\text { depth }\end{array}$ & Too easy & Too difficult & $\begin{array}{l}\text { Too } \\
\text { theoretical }\end{array}$ & $\begin{array}{l}\text { Too } \\
\text { practical }\end{array}$ & $\begin{array}{l}\text { Too few } \\
\text { options }\end{array}$ & $\begin{array}{l}\text { Too many } \\
\text { options }\end{array}$ & $\begin{array}{l}\text { Challenging } \\
\text { with regard to } \\
\text { the level } \\
\text { logit }\end{array}$ \\
\hline Narrow programme & $-0.139^{* *}$ & $-0.120^{*}$ & 0.055 & 0.013 & $-0.181^{* *}$ & 0.165 & $0.241 * * *$ & 0.024 & -0.079 & 0.149 & 0.044 & 0.235 & 0.024 \\
\hline Female & 0.029 & 0.075 & -0.008 & 0.051 & -0.049 & $-0.352 *$ & $-0.156^{*}$ & $0.170^{* *}$ & $-0.567 * * *$ & 0.142 & 0.097 & -0.153 & $0.170 * *$ \\
\hline Age & $-0.472 * * *$ & -0.100 & 0.242 & 0.248 & 0.262 & 0.233 & 0.138 & 0.145 & 0.209 & 0.226 & -0.145 & 0.116 & 0.145 \\
\hline $\mathrm{Age}^{2}$ & $0.009^{* * *}$ & 0.002 & -0.006 & -0.004 & -0.005 & $-0,003$ & -0.003 & -0.002 & -0.006 & -0.003 & 0.003 & -0.001 & -0.002 \\
\hline No further education & ref. & ref. & ref. & ref. & ref. & ref. & ref. & ref. & ref. & ref. & ref. & ref. & ref. \\
\hline Education interrupted & $-0.260^{* *}$ & $-0.282 * * *$ & 0.133 & -0.300 & $0.289^{* *}$ & 0.191 & $0.266 * *$ & -0.025 & -0.172 & $1.146^{* * *}$ & 0.004 & -0.205 & -0.025 \\
\hline $\begin{array}{l}\text { Education completed } \\
\text { or partial certificate }\end{array}$ & 0.220 & 0.238 & $-1.914 *$ & -0.597 & -0.405 & -1.092 & -0.339 & 0.210 & -0.206 & 0.825 & -0.742 & 0.516 & 0.210 \\
\hline 2006 & $-0.396 * * *$ & $-0.279 * * *$ & -0.088 & $-0.322 * *$ & 0.151 & 0.335 & 0.004 & -0.032 & 0.000 & 0.000 & $-0.321 * *$ & $-0.630 * * *$ & -0.032 \\
\hline 2007 & $-0.171 * *$ & $-0.218 * * *$ & -0.018 & 0.012 & 0.100 & -0.050 & 0.056 & -0.061 & $0.159 *$ & 0.138 & $-0.208^{*}$ & -0.031 & -0.061 \\
\hline 2008 & ref. & ref. & ref. & ref. & & & ref. & ref. & ref. & ref. & ref. & ref. & ref. \\
\hline Constant & $6.081^{* * *}$ & 1.720 & -4.811 & $-5.561^{*}$ & $-4.689^{*}$ & -6.899 & -2.801 & -3.219 & -2.765 & -7.163 & -0.528 & -4.962 & -3.219 \\
\hline Nagelkerke $\mathrm{R}^{2}$ & 0.014 & 0.009 & & & & & & 0.010 & 0.0 & & & & 0.005 \\
\hline -2 Log likelihood & 5164.732 & 5102.522 & & 190 & 102 & & & 951.944 & 709.1 & & & & 4450.150 \\
\hline $\mathrm{N}$ & 3757 & 3756 & & & & & & 3746 & 287 & & & & 3881 \\
\hline
\end{tabular}




\section{References}

Borghans L, Grip A de (1999). Smal en breed opleiden: productiviteit versus flexibiliteit. In: Gids voor de Opleidingspraktijk 28:1-33. Samsom, Deventer.

Borghans L, Heijke H (2004) Promoting the macro-efficiency of vocational education? In: Nijhof WJ, van Esch W (ed) Unraveling Policy, Power, Process and Performance: The Formative Evaluation of the Dutch Adult and Vocational Education Act. CINOP, 's-Hertogenbosch, pp 79-98

Dolton P, Vignoles A (2002) Is a broader curriculum better? Econ Educ Rev 21:415-429

Grip A de, Heijke H (1989) Het flexibiliteitspotentieel van universitaire studierichtingen. Tijdschrift voor Arbeidsvraagstukken 5 (4):69-81

Grip A de, Marey P (2006) Het werkveld van bètatechnici. In: Grip A de, Marey P (ed) Technotopics, Essays over onderwijs en arbeidsmarkt voor bètatechnici. Platform Bèta Techniek, The Hague, pp $47-54$

Heijke H (2001) Vocational education from an economic point of view. In: Nieuwenhuis LFM, Nijhof WJ (ed) The Dynamics of Vet and HRD Systems. Twente University Press, Enschede, pp 169-180

Heijke H (2008) Working on heterogeneous human capital. ROA-TR-2008/6. Research Centre for Education and the Labour Market, Maastricht

Heijke H, Borghans L (1998) Investing in education. In: Heijke H, Borghans L (ed) Towards a Transparent Labour Market for Educational Decisions. Ashgate, Aldershot (UK), pp 1-18

Heijke H, Meng C, Ramaekers G (2003a) An investigation into the role of human capital competencies and their pay-off. Int J Manpower 24 (7):750-773

Heijke H, Meng C, Ris C (2003b) Fitting to the job: The role of generic and vocational competencies in adjustment and performance. Labour Econ 10 (2):215-229

Hoof JJ van, Dronkers J (1980) Onderwijs en arbeidsmarkt: Een verkenning van de relatie tussen onderwijs, arbeidsmarkt en arbeidssysteem. Van Loghum Slaterus, Deventer

Jovanovic B (1979) Job matching and the theory of turnover. J Polit Econ 87:1246-1260

Nijhof WJ (1998) Qualifying for the future. In: Nijhof WJ, Streumer JN (ed) Key Qualifications in Work and Education. Kluwer Academic Publishers, Boston, pp 19-38

Research Centre for Education and the Labour Market (ROA) (2007) De arbeidsmarkt naar opleiding en beroep tot 2012. ROA-R-2007/4. Research Centre for Education and the Labour Market, Maastricht

Research Centre for Education and the Labour Market (ROA) (2010) Schoolverlaters tussen onderwijs en arbeidsmarkt 2009. ROA-R-2010/7. Research Centre for Education and the Labour Market, Maastricht

Research Centre for Education and the Labour Market (ROA) (2011) Schoolverlaters tussen onderwijs en arbeidsmarkt 2010. ROA-R-2011/7. Research Centre for Education and the Labour Market, Maastricht

Sattinger M (1993) Assignment models of the distribution of earnings. J Econ Lit 31:831-880

Statistics Netherlands (2011) Statistical Yearbook 2011. Statistics Netherlands, The Hague 